UNITED STATES

DEPARTMENT OF THE INTERIOR

GEOLOGICAL SURVEY

\title{
RECONNAISSANCE OF SURFACE-WATER RESOURCES IN THE KOBUK RIVER BASIN, ALASKA, 1979-80
}

By Joseph M. Childers and Donald R. Kernodle

U. S. GEOLOGICAL SURVEY

WATER-RESOURCES INVESTIGATIONS REPORT 83-4027

Prepared in cooperation with

ALASKA DEPARTMENT OF NATURAL RESOURCES

DIVISION OF GEOLOGICAL AND GEOPHYSICAL SURVEYS

Anchorage, Alaska

1983 


\section{UNITED STATES DEPARTMENT OF THE INTERIOR \\ JAMES G. WATT, Secretary \\ GEOLOGICAL SURVEY \\ Dallas Peck, Director}

For additional information write to:

\section{U.S. Geological Survey} Water Resources Division 1515 East 13th Avenue Anchorage, Alaska 99501
Copies of this report can be purchased from:

Open-File Services Section Western Distribution Branch U.S. Geological Survey Box 25425, Federal Center Denver, Colorado 80225 (Telephone: (303) 234-5888) 
Abstract $\ldots \ldots \ldots \ldots \ldots \ldots \ldots \ldots \ldots \ldots \ldots \ldots \ldots \ldots \ldots \ldots \ldots \ldots \ldots \ldots \ldots \ldots$

Introduction $\ldots \ldots \ldots \ldots \ldots \ldots \ldots \ldots \ldots \ldots \ldots \ldots \ldots \ldots \ldots \ldots \ldots \ldots$

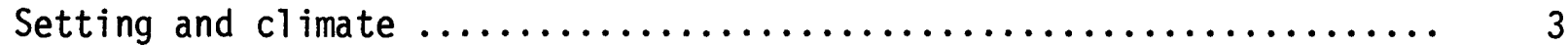

Seasonal variations in hydrology $\ldots \ldots \ldots \ldots \ldots \ldots \ldots \ldots \ldots \ldots \ldots \ldots \ldots \ldots$

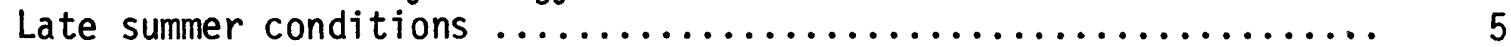

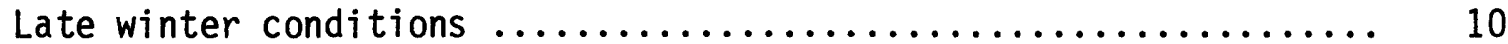

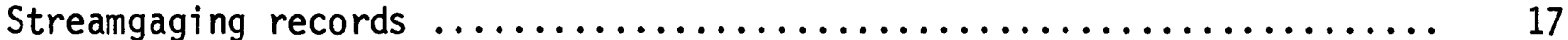

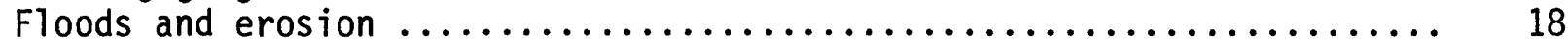

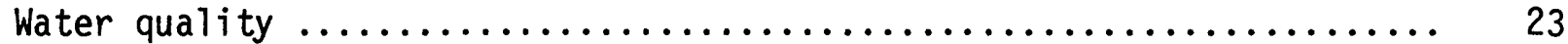

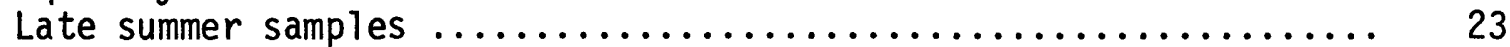

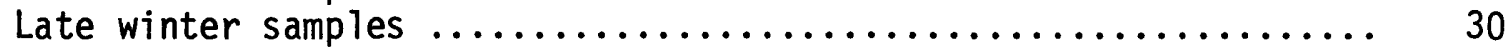

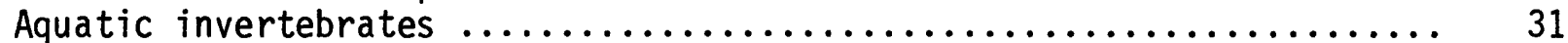

Data and information needs for future planning $\ldots \ldots \ldots \ldots \ldots \ldots \ldots \ldots \ldots$

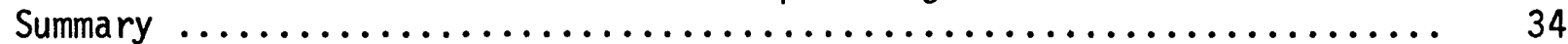

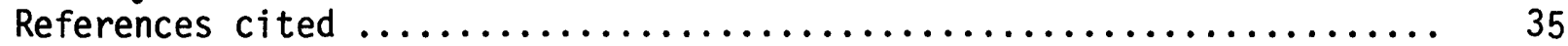

\section{ILLUSTRATIONS}

1. Map showing index of U.S. Geological Survey topographic maps by

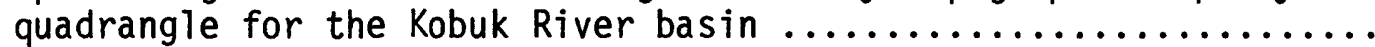

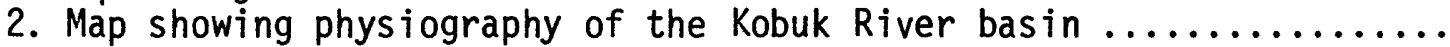

3. Profile of the Kobuk River and position of tributary junctions .... 6, 7

4. Map showing site locations, surveys of August 1979, Kobuk River

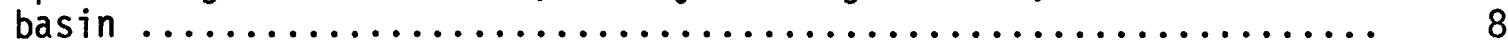

5. Kobuk River cross sections, August $1979 \ldots \ldots \ldots \ldots \ldots \ldots \ldots \ldots \ldots \ldots \ldots$

6. Aerial photograph of Walker Lake outlet, June $1,1979 \ldots \ldots \ldots \ldots \ldots .12$

7. Photograph of Walker Lake outlet, August 11, 1979, from left bank,

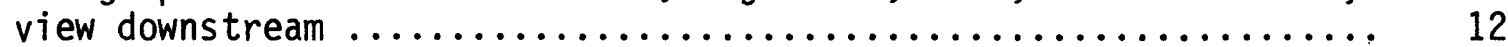

8. Aerial photograph of Lower Kobuk Canyon rapids, June 1, 1979...... 13

9. Close-up aerial photograph of Lower Kobuk Canyon rapids, August 14,

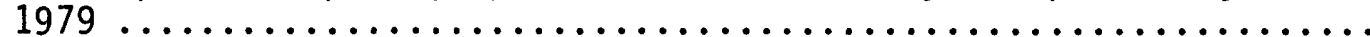

10. Map showing site locations, surveys of March and Apri1 1980, Kobuk

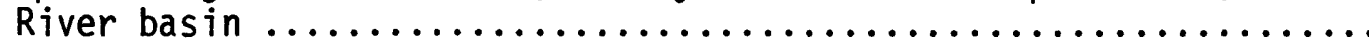

11. Photograph of overflow ice on Shungnak River near Shungnak, April

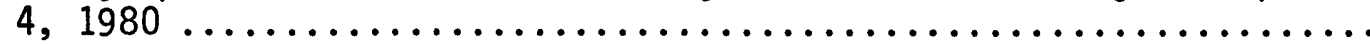

12. Photograph of Canyon Creek near Kiana at survey site, March 23, 1980

13. Photograph of icing on Canyon Creek near Kiana, March 23, $1980 \ldots$

14. Photographs of bank erosion and ice in bank along Kobuk River near Shungnak, August 26, 1979 
TABLES

Page

1. Stream site descriptions, surveys of August 1979 in Kobuk River

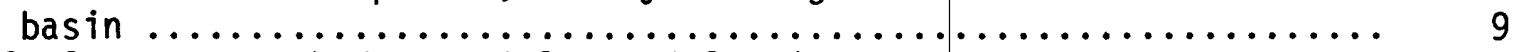

2. Scale of streambed material particle sizes ................. 10

3. Discharge measurements during March and April 1980 in Kobuk River

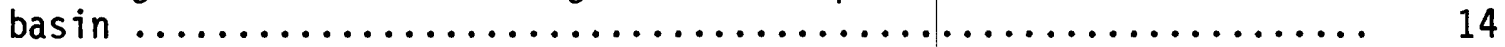

4. Flow characteristics of Kobuk River at Ambler ............... 18

5. Bankfull channel, maximum evident flood, bas in, and flood characteristics at flood survey sites in the Kobuk River basin, $1979 \ldots \ldots .20$

6. Selected water-quality data from Kobuk River at Ambler .......... 24

7. Selected water-quality data from Kobuk River near Kiana .......... 25

8. Water quality and related parameters from selected sites in Kobuk River basin, August 1979 ........................... 26-29

9. Water quality and related parameters from sites in Kobuk River basin, March and April 1980 ............................ 31

10. Aquatic organisms collected by dip net at sites within the Kobuk River basin, August 1979 ................................ 32

\section{CONVERSION TABLE}

\section{Multiply}

inch (in.)

foot $(\mathrm{ft})$

mile (mi)

square mile $\left(m i^{2}\right)$

mile per hour ( $\mathrm{mi} / \mathrm{h})$

foot per mile $(\mathrm{ft} / \mathrm{mi})$

foot per second $(\mathrm{ft} / \mathrm{s})$

cubic foot per second $\left(\mathrm{ft}^{3} / \mathrm{s}\right)$

cubic foot per second per

square mile $\left[\left(\mathrm{ft}^{3} / \mathrm{s}\right) / \mathrm{mi}^{2}\right]$

degree Fahrenheit $\left({ }^{\circ} \mathrm{F}\right)$

micromho per centimeter at

$25^{\circ} \mathrm{C}(\mu \mathrm{mho} / \mathrm{cm})$
By

25.40

0.3048

1.609

2.590

1.609

0.1894

0.3048

0.02832

0.0109

$\left({ }^{\circ} \mathrm{F}-32\right) 0.555$

1
To obtain

millimeter $(\mathrm{mm})$

meter $(\mathrm{m})$

kilometer $(\mathrm{km})$

square kilometer $\left(\mathrm{km}^{2}\right)$

$\mathrm{kilometer}$ per hour $(\mathrm{km} / \mathrm{h})$

meter per kilometer $(\mathrm{m} / \mathrm{km})$

meter per second $(\mathrm{m} / \mathrm{s})$

cubic meter per second $\left(\mathrm{m}^{3} / \mathrm{s}\right)$

cubic meter per second per square kilometer $\left[\left(\mathrm{m}^{3} / \mathrm{s}\right) / \mathrm{km}^{2}\right]$ degree Celsius $\left({ }^{\circ} \mathrm{C}\right)$

microsiemen per centimeter at $25^{\circ} \mathrm{C}(\mu \mathrm{S} / \mathrm{cm})$

Other abbreviations in this report are:

$\mu \mathrm{g} / \mathrm{L}$, micrograms per liter

$\mathrm{mg} / \mathrm{L}$, milligrams per liter

Note: The National Geodetic Vertical Datum of 1929 (NGVD of 1929) is a geodetic datum derived from a general adjustment of the first-order level nets of both the United States and Canada, formerly called mean sea level. NGVD of 1929 is referred to as sea level in this report. 


\begin{abstract}
RECONNAISSANCE OF SURFACE-WATER RESOURCES IN THE KOBUK RIVER BASIN,
ALASKA , $1979-80$
\end{abstract}

By Joseph M. Childers and Donald R. Kernodle

\title{
ABSTRACT
}

Surface-water data were collected at selected sites in the Kobuk River bas in in northwest Alaska in August 1979 and April 1980. In August 1979, frequent heavy rains caused abnormally high flows in the basin; unit runoff values, computed from discharge measurements at 25 sites, ranged from 0.08 to 12.2 cubic feet per second per square mile. Mean unit runoff for August computed from 13 years of record at a streamgaging station on the Kobuk River ranged from 1 to 3 cubic feet per second per square mile. Unit runoff computed from discharge measurements made at eight sites in April 1980 ranged from 0 to 0.30 cubic feet per second per square mile. These values are in reasonable agreement with those derived from the record at the gaging station.

High-water marks of maximum evident floods and evidence of ice-affected flooding were found at near bankfull stages at 17 sites on the Kobuk River and its tributaries. Computed unit runoff for the maximum evident floods generally decreases with increasing drainage area. Unit runoff ranges from about 50 to 75 cubic feet per second per square mile for drainage areas less than 1,000 square miles to less than 25 cubic feet per second per square mile for larger areas.

Field determinations were made of water temperature, $\mathrm{pH}$, alkalinity, dissolvedoxygen concentration, and specific conductance, and discharge was measured at about 40 stream sites and one spring. Water samples for laboratory analys is of dissolved inorganic constituents and biological samples were collected in August 1979. Water-quality data indicate that the surface waters would be acceptable for most uses; they are a calcium bicarbonate type having dissolved-solids concentrations generally between about 50 and 140 milligrams per liter. The pristine nature of the waters is also indicated by the overall diversity and composition of its benthic invertebrate community. A more highly mineralized (about 550 milligrams per liter dissolved solids) sodium bicarbonate water flows from Reed River Hot Spring.

\section{INTRODUCTION}

The Kobuk River basin in northwest Alaska has been virtually undisturbed by man's activities. Parts of the basin are included in either the Kobuk Valley National Park or the Gates of the Arctic National Park and Preserve. The upper reach of the Kobuk River (above Selby River) was added to the National Wild and Scenic Rivers System under provisions of the Alaska National Interest Land Conservation Act (ANILCA) of 1980. The Salmon River, a large tributary of the Kobuk, was also designated a Wild and Scenic River, and the Squirrel River, a smaller tributary, is now being studied by the National Park System for possible inclusion in the system. 


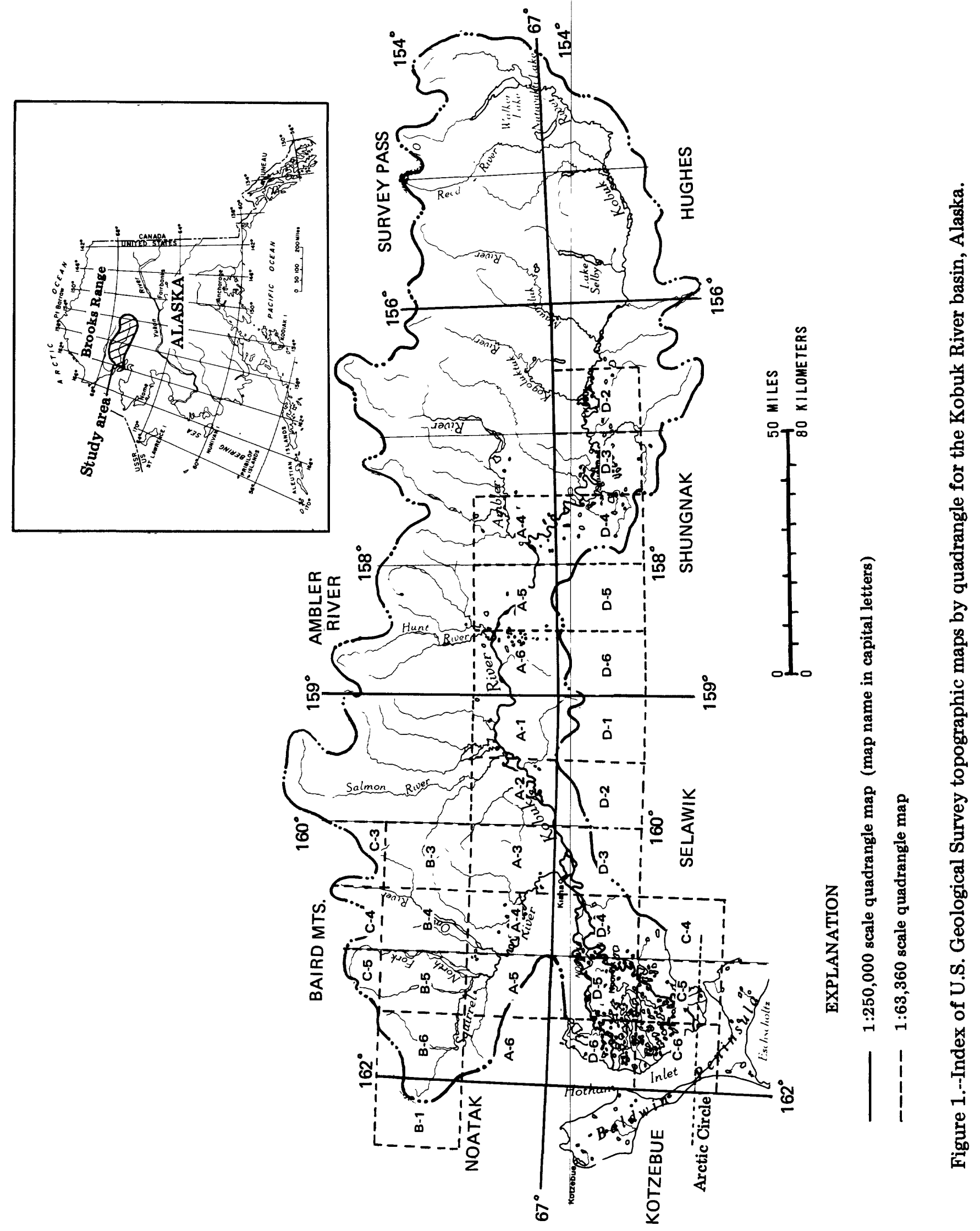


This report contains data on physiographic and climatic characteristics of the Kobuk River basin, as well as stream channel hydraulic properties, seasonal quantity and quality of surface waters, floods, channel erosion, and benthic invertebrates. The data show the magnitude and ranges of stream discharge, width, depth, and velocity of flow that can be expected in late winter and summer periods, and indicate flood and erosion hazards in the basin. The water-quality and benthicinvertebrate data could be used to evaluate the suitability of the water for proposed uses and as a base from which to measure future changes in water quality. Data needs for management of the water resources of the Kobuk basin are discussed in the final section of the report.

Hydrologic reconnaissance surveys were made in the Kobuk River basin in August 1979 (late summer in northern Alaska) by boat and helicopter and in March and April 1980 (late winter) by snowmobile. Personnel from Alaska Department of Natural Resources, Division of Geological and Geophysical Surveys, assisted the authors in the data collection.

This report is a product of a U.S. Geological Survey program, under way since the early 1970's, to study environmental conditions in selected frontier areas of Alaska where development has begun or is planned. This program has been conducted primarily in the Arctic region (north of the Yukon River) and along existing or proposed transportation corridors. Numerous reports have been published, including results of a study of surface-water resources of the Noatak River basin (Childers and Kernodle, 1981).

\section{SETTING AND CLIMATE}

The Kobuk River basin has an area of $11,980 \mathrm{mi}^{2}$ (Selkregg, 1976). It lies south of the western part of the Brooks Range and just north of the Arctic Circle (fig. 1). The basin contains five villages along the Kobuk River (Kobuk, Shungnak, Ambler, Kiana, and Noorvik) (fig. 2). Bornite, a mining camp, is on Ruby Creek, a tributary to the Shungnak River which is a major tributary of the Kobuk River. Abandoned mining camps and settlements are scattered throughout the Kobuk basin. A few people live in isolated cabins, most of which are along streams. Temporary camps are seasonally occupied for fishing and mining. Transportation in the basin is by boat in the summer, snowmobile in the winter, and aircraft year round. Unpaved roads connect Kobuk village with nearby mines and winter trails are used for access between Kotzebue and inland villages.

The Kobuk River originates in the Central and Eastern Brooks Range (fig. 2). It then flows westward for more than $300 \mathrm{mi}$ through the Kobuk-Selawik Lowland (Wahrhaftig, 1965) to its delta on Hotham Inlet (locally called Kobuk Lake). Most of the drainage is from the Baird and Schwatka Mountains, which are extensions of the Brooks Range to the north. The river passes through two canyons, Upper and Lower Kobuk Canyons.

The slope of the Kobuk River (fig. 3) is about $0.4 \mathrm{ft} / \mathrm{mi}$ between Kobuk village and its mouth at Hotham Inlet. In the approximately 110 mi from the rapids at the outlet of Walker Lake to Kobuk village, the elevation difference is about $500 \mathrm{ft}$ and the slope is about $4.5 \mathrm{ft} / \mathrm{mi}$. The tributaries have much steeper slopes. Figure 3 may be used to estimate distance along the river between indicated points, as well as slope and range in elevation of the particular reach. 


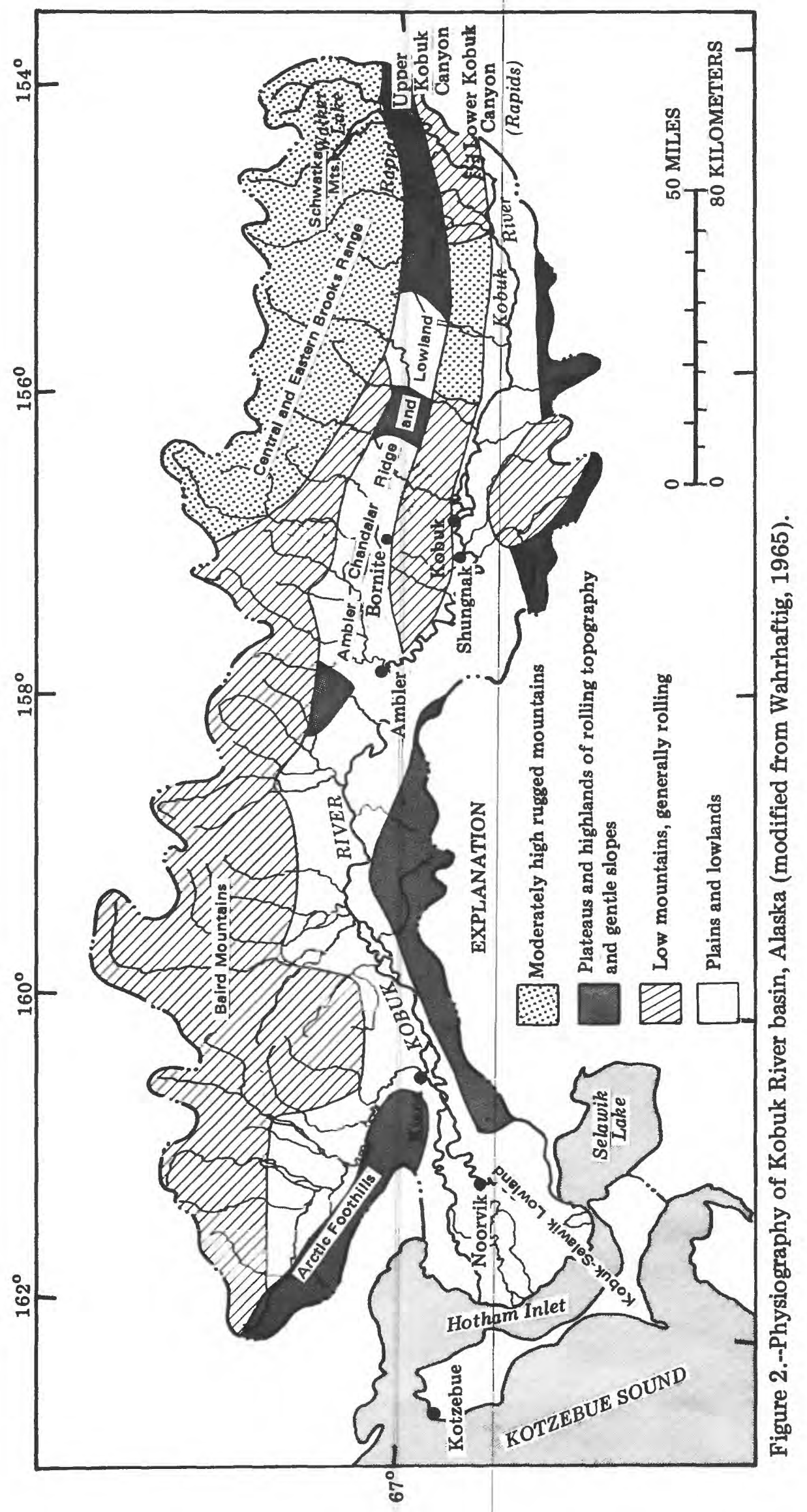


Long, severe winters dominate the Kobuk River basin climate. Summers are often wet, and rainfall generally increases as summer progresses. Fog, rain, snow, and whiteout conditions are common. Daylight is continuous from May to August, but in December darkness prevails except for 6 to 7 hours of twilight each day. Weather records for Kobuk indicate that winter temperatures range from $-24^{\circ}$ to $1^{\circ} \mathrm{F}$, and summer temperatures range from $42^{\circ}$ to $69^{\circ} \mathrm{F}$. Precipitation averages 20 in. annually, which includes $56 \mathrm{in.}$ of snow. In this part of Alaska, winds average 10 to 15 knots the year-round (Selkregg, 1976, p. 16).

\section{SEASONAL VARIATIONS IN HYDROLOGY}

The Arctic climate strongly affects hydrologic conditions in the Kobuk River basin. Streams begin to freeze in 0ctober, and streamflow decreases through the winter to reach its annual low-flow period in March and April. The ice cover on most streams breaks up in May, and peak flows from snow-melt runoff occur in May and June. High-altitude streams freeze earlier and break up later. Summer rainstorms are common and can cause high stream discharge and flooding. Permafrost is discontinuous, but restricts infiltration where it is present.

\section{Late Summer Conditions}

Late summer weather in the Kobuk River basin varies from clear and warm to cloudy, rainy, and cold. If summer is mostly clear and warm with little or no rainfall, stream discharges are relatively low, exposed gravel bars are common, and flow is confined to the gravel-armored streambeds. If summer is mostly rainy, stream levels are high and the water may be quite turbid due to bank erosion.

Stream discharge measurements were made at 26 sites during the period August 11-29, 1979 (fig. 4 and table 1). Frequent, heavy rains occurred during the middle and latter part of August. Thus streamflow was probably higher than normal; measured discharge increased from $1,090 \mathrm{ft}^{3} / \mathrm{s}$ above Walker Lake outlet (site 1) to 50,800 $\mathrm{ft}^{3} / \mathrm{s}$ below Jade Creek (site 26). Flow at Kobuk River below Onion Portage and at Squirrel River and its tributaries was too great to measure using the equipment available.

Unit runoff, a value obtained by dividing stream discharge by drainage area, can be used to compare seasonal water yields in a basin or yields from different parts of a basin. Unit runoff in August 1979 increased from between 3.3 and $4.5\left(\mathrm{ft}^{3} / \mathrm{s}\right) / \mathrm{mi}^{2}$ in the upper Kobuk River (sites 1, 4, 8, and 10) to $7.6\left(\mathrm{ft}^{3} / \mathrm{s}\right) / \mathrm{mj}^{2}$ below Jade Creek (site 26) in the middle reach of the river. Rainfall during the time between measurements most likely accounts for this increase. However, even the lower values are probably higher than normal for August, based on records from the longterm streamgaging station, Kobuk River at Ambler (site 24, fig. 4).

Unit runoff for the Kobuk River tributaries ranged from $0.1\left(\mathrm{ft}^{3} / \mathrm{s}\right) / \mathrm{mi}^{2}$ at the outlet of Kollioksak Lake (site 14) to $12.2\left(\mathrm{ft}^{3} / \mathrm{s}\right) / \mathrm{mi}^{2}$ at Akillik River (site 27). Most major tributaries draining the Baird and Schwatka Mountains from the north had significantly higher unit runoff than tributaries draining the lower relief areas from the south. The discharge measurement of one of these southern tributaries, the Pah River (site 11), indicated that unit runoff was $0.5\left(\mathrm{ft}^{3} / \mathrm{s}\right) / \mathrm{mi}^{2}$. 


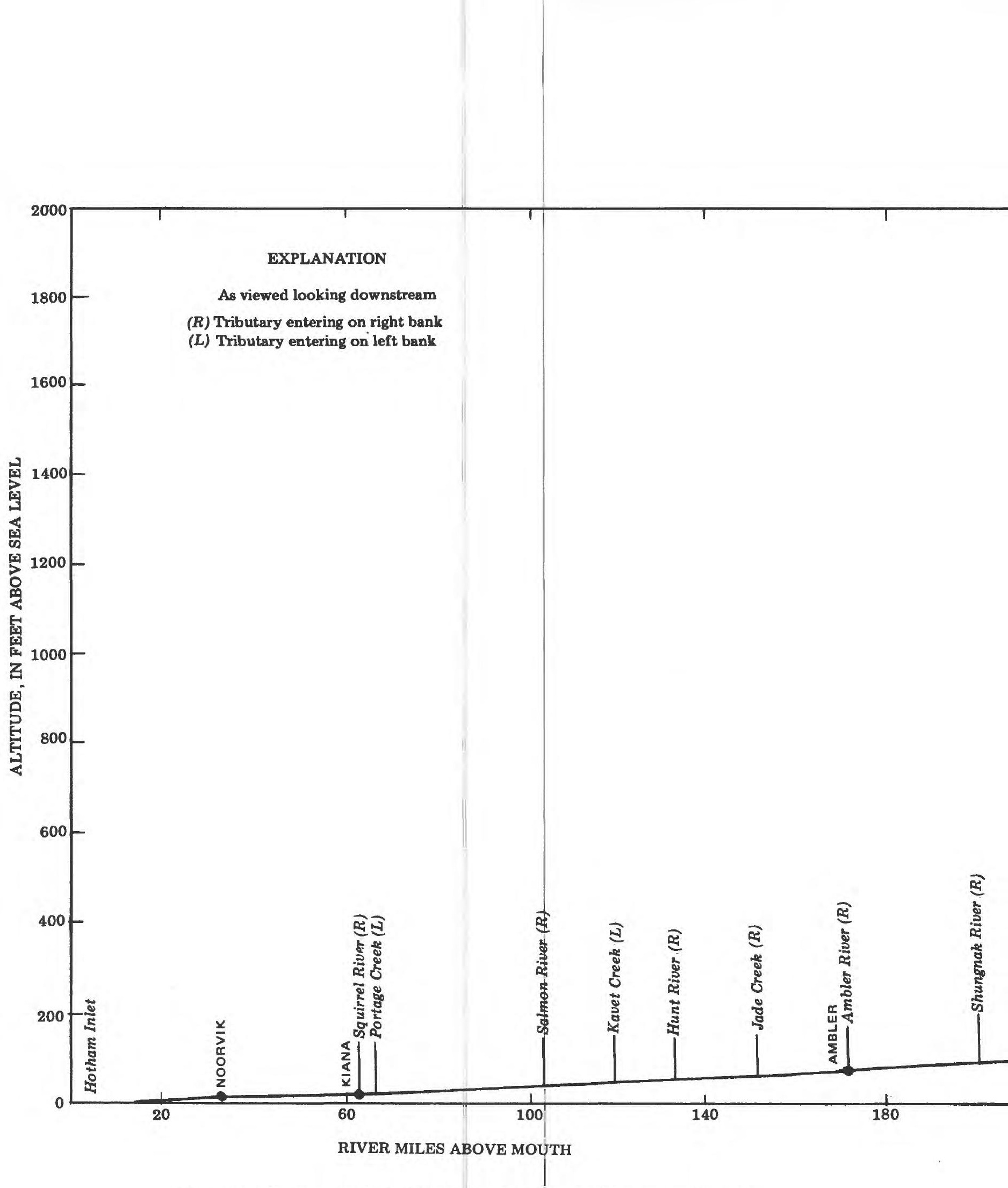

Figure 3.--Profile of Kobuk River and position of tributary junctions. 


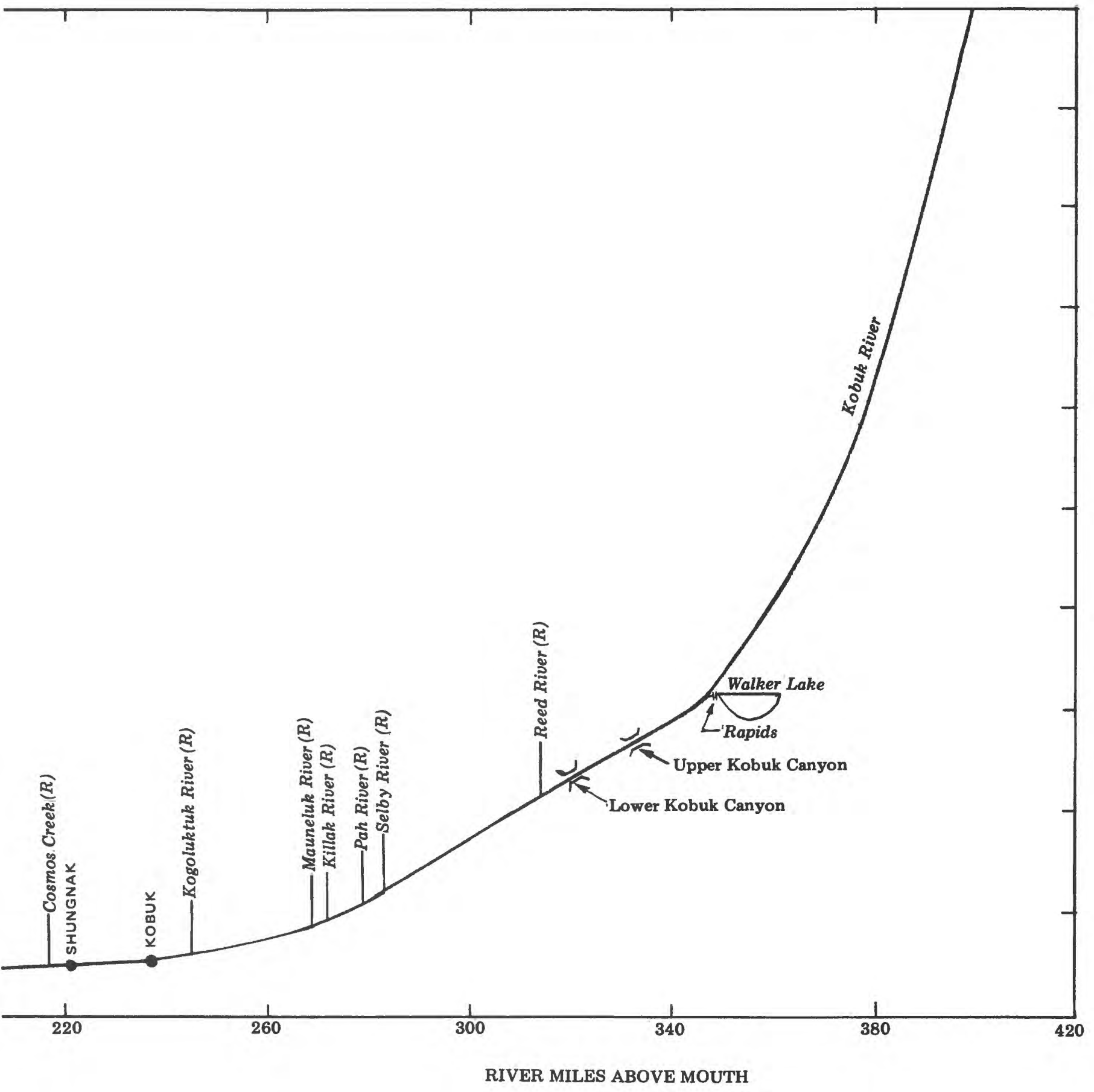




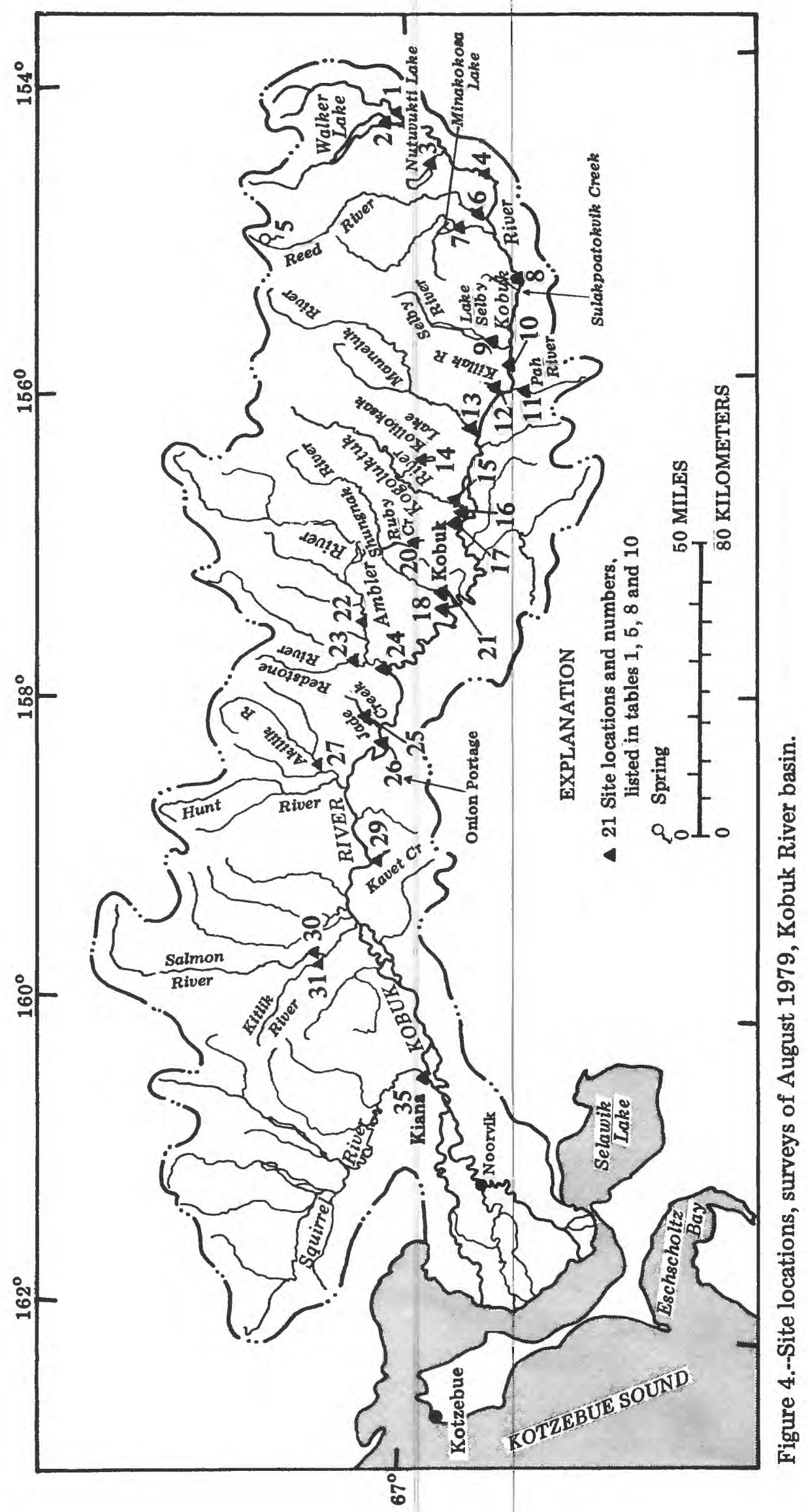


Table 1. - Stream site descriptions, surveys of August 1979 in Kobuk River basin [See figure 4 for site locations]

\begin{tabular}{|c|c|c|c|c|c|c|c|c|c|c|c|c|}
\hline $\begin{array}{l}\text { Site } \\
\text { no. }\end{array}$ & $\begin{array}{l}\text { Stream site } \\
\text { (lat, long) }\end{array}$ & $\begin{array}{l}\text { Kobuk } \\
\text { River } \\
\text { mile }\end{array}$ & $\begin{array}{l}\text { Dra inage } \\
\text { area } \\
\left(m i^{2}\right)\end{array}$ & $\begin{array}{c}\text { Date } \\
\text { measured } \\
\text { (day) }\end{array}$ & $\begin{array}{c}\text { Discharge } \\
\left(\mathrm{ft}^{3} / \mathrm{s}\right)\end{array}$ & $\begin{array}{l}\text { Unit runoff } \\
{\left[\left(\mathrm{ft}^{3} / \mathrm{s}\right) / \mathrm{mi}^{2}\right]}\end{array}$ & $\begin{array}{r}\text { Width } \\
(\mathrm{ft})\end{array}$ & $\begin{array}{l}\text { Mean } \\
\text { depth } \\
(\mathrm{ft})\end{array}$ & $\begin{array}{l}\text { Maximum } \\
\text { depth } \\
(\mathrm{ft})\end{array}$ & $\begin{array}{l}\text { Mean } \\
\text { velocity } \\
(\mathrm{ft} / \mathrm{s})\end{array}$ & $\begin{array}{l}\text { Maximum } \\
\text { surface } \\
\text { velocity } \\
(\mathrm{ft} / \mathrm{s})\end{array}$ & $\begin{array}{c}\text { Bed } \\
\text { material } \\
\text { (table 2) } \\
\end{array}$ \\
\hline 1 & $\begin{array}{l}\text { Kobuk River above Walker } \\
\text { Lake outlet }\left(67^{\circ} 01^{\prime} 37^{\prime \prime} \text {, }\right. \\
\left.154^{\circ} 20^{\prime} 36^{\prime \prime}\right) \text {. }\end{array}$ & 349 & 285 & 11 & 1,090 & 3.82 & 217 & 1.5 & 2.7 & 3.4 & 4.7 & Cobbles, gravel. \\
\hline 2 & $\begin{array}{l}\text { Walker Lake outlet } \\
\left(67^{\circ} \mathrm{D} 3^{\prime} 29^{\prime \prime}, 154^{\circ} 18^{\prime} 49^{\prime \prime}\right) \text {. }\end{array}$ & -- & 178 & 11 & 1,160 & 6.52 & 195 & 2.1 & 4.4 & 2.8 & 3.5 & $\begin{array}{l}\text { Boulders, gravel, } \\
\text { sand. }\end{array}$ \\
\hline 3 & $\begin{array}{l}\text { Nutuvukti Lake outlet } \\
\left(66^{\circ} 57^{\prime} 19^{\prime \prime}, 154^{\circ} 35^{\prime} 50^{\prime \prime}\right) .\end{array}$ & -- & 29 & 14 & 47 & 1.62 & 30 & 2.1 & 2.8 & .75 & 1.1 & Grave1, sand. \\
\hline 4 & $\begin{array}{l}\text { Kobuk River above Lower } \\
\text { Kobuk Canyon }\left(66^{\circ} 50^{\prime} 06^{\prime \prime} \text {, }\right. \\
\left.154^{\circ} 39^{\prime} 00^{\prime \prime}\right) \text {. }\end{array}$ & 323 & 714 & 13 & 2,380 & 3.33 & 347 & 3.2 & 5.0 & 2.1 & 2.6 & $\begin{array}{l}\text { Cobbles, gravel, } \\
\text { sand. }\end{array}$ \\
\hline 5 & $\begin{array}{l}\text { Reed River Hot Spring near } \\
\text { Kobuk }\left(67^{\circ} 15^{\circ} 50^{\prime \prime}, 155^{\circ} 02^{\prime} 39^{\prime \prime}\right) \text {. }\end{array}$ & -- & -- & 15 & 0.3 & -- & 1.3 & 0.2 & 0.3 & 1.0 & 1.9 & Rock. \\
\hline 6 & $\begin{array}{l}\text { Reed River near mouth } \\
\left(66^{\circ} 49^{\prime} 25^{\prime \prime}, 154^{\circ} 57^{\prime} 31^{\prime \prime}\right) \text {. }\end{array}$ & -- & 364 & 15 & 1,640 & 4.51 & 268 & 2.4 & 3.5 & 2.5 & 3.2 & Gravel, sand. \\
\hline 7 & $\begin{array}{l}\text { Minakokosa Lake outlet } \\
\left(66^{\circ} 54^{\circ} 23^{\prime \prime}, 155^{\circ} 00^{\prime} 44^{\prime \prime}\right) \text {. }\end{array}$ & -- & 33 & 14 & 88 & 2.70 & 78 & 2.8 & 3.4 & 0.4 & .55 & Silt, sand. \\
\hline 8 & $\begin{array}{l}\text { Kobuk River above Sulak- } \\
\text { poatokvik Creek } \\
\left(66^{\circ} 46^{\prime} 36^{\prime \prime}, 155^{\circ} 10^{\prime} 18^{\prime \prime}\right) \text {. }\end{array}$ & 302 & 1,560 & 16 & 6,930 & 4.45 & 432 & 4.0 & 5.5 & 4.0 & 5.2 & Cobble, gravel. \\
\hline 9 & $\begin{array}{l}\text { Lake Selby outlet } \\
\left(66^{\circ} 51^{\prime} 04^{\prime \prime}, 155^{\circ} 41^{\prime} 04^{\prime \prime}\right) \text {. }\end{array}$ & - & 113 & 16 & 332 & 2.94 & 260 & 1.7 & 2.7 & .75 & .94 & $\begin{array}{l}\text { Boulder, cobbles, } \\
\text { gravel. }\end{array}$ \\
\hline 10 & $\begin{array}{l}\text { Kobuk River below Selby } \\
\text { River }\left(66^{\circ} 46^{\prime} 18^{\prime \prime}, 155^{\circ} 50^{\prime} 00^{\prime \prime}\right) \text {. }\end{array}$ & 282 & 2,000 & 17 & 7,240 & 3.62 & 398 & 4.5 & 7.0 & 4.0 & 6.0 & Cobbles, gravel. \\
\hline 11 & $\begin{array}{l}\text { Pah River near mouth } \\
\left(66^{\circ} 44^{\prime} 30^{\prime \prime}, 156^{\circ} 03^{\prime} 48^{\prime \prime}\right) \text {. }\end{array}$ & -- & 956 & 17 & 458 & .48 & 195 & 2.3 & 3.3 & 1.0 & 1.5 & Do. \\
\hline 12 & $\begin{array}{l}\text { Killak River near mouth } \\
\left(66^{\circ} 48^{\prime} 54^{\prime \prime}, 156^{\circ} 05^{\prime} 00^{\prime \prime}\right) \text {. }\end{array}$ & -- & 42 & 18 & 92 & 2.19 & 27 & 1.2 & 2.5 & 2.9 & 3.6 & Do. \\
\hline 13 & $\begin{array}{l}\text { Mauneluk River near mouth } \\
\left(66^{\circ} 52^{\prime} 40^{\prime \prime}, 156^{\circ} 16^{\prime} 45^{\prime \prime}\right) \text {. }\end{array}$ & -- & 573 & 18 & 2,980 & 5.20 & 281 & 2.7 & $\begin{array}{l}4.5 \\
\text { est. }\end{array}$ & 3.9 & $\begin{array}{l}4.5 \\
\text { est. }\end{array}$ & $\begin{array}{l}\text { Boulder, cobble, } \\
\text { gravel. }\end{array}$ \\
\hline 14 & $\begin{array}{l}\text { Kollioksak Lake outlet } \\
\left(66^{\circ} 59^{\prime} 43^{\prime \prime}, 156^{\circ} 26^{\prime} 31^{\prime \prime}\right) .\end{array}$ & -- & 6 & 18 & est. & .08 & 14 & 3.5 & -- & $\begin{array}{l}.01 \\
\text { est. }\end{array}$ & -- & Soft silt. \\
\hline 15 & $\begin{array}{l}\text { Kogoluktuk River near mouth } \\
\left(66^{\circ} 56^{\prime} 42^{\prime \prime}, 156^{\circ} 45^{\prime} 06^{\prime \prime}\right) \text {. }\end{array}$ & -- & 626 & 19 & 2,540 & 4.06 & 284 & 2.3 & $\begin{array}{l}3.5 \\
\text { est. }\end{array}$ & 4.0 & $\begin{array}{l}4.5 \\
\text { est. }\end{array}$ & Boulder, cobble. \\
\hline 16 & $\begin{array}{l}\text { Kobuk River above Kobuk } \\
\left(66^{\circ} 54^{\prime} 12^{\prime \prime}, 156^{\circ} 53^{\prime} 06^{\prime \prime}\right)\end{array}$ & 237 & 4,170 & 24 & 21,900 & 5.25 & 627 & 9.6 & 12.5 & 3.7 & 4.8 & Cobble, gravel. \\
\hline 20 & $\begin{array}{l}\text { Ruby Creek at Bornite } \\
\left(67^{\circ} 04^{\prime} 36^{\prime \prime}, 156^{\circ} 56^{\prime} 12^{\prime \prime}\right) .\end{array}$ & -- & 13 & 21 & 80 & 6.15 & 26 & .9 & 1.0 & 3.5 & 4.3 & Do. \\
\hline 21 & $\begin{array}{l}\text { Shungnak River near mouth } \\
\text { near Shungnak }\left(66^{\circ} 56^{\prime} 47^{\prime \prime} \text {, }\right. \\
\left.157^{\circ} 19^{\prime} 03^{\prime \prime}\right) \text {. }\end{array}$ & -- & 213 & 23 & 1,520 & 7.14 & 175 & 2.4 & $\begin{array}{l}4.0 \\
\text { est. }\end{array}$ & 3.6 & 4.3 & Boulder, cobble. \\
\hline 22 & $\begin{array}{l}\text { Ambler River above Redstone } \\
\text { River }\left(67^{\circ} 09^{\prime} 18^{\prime \prime}, 157^{\circ} 32^{\prime} 23^{\prime \prime}\right) \text {. }\end{array}$ & -- & 716 & 19 & $5, \mathrm{D} 30$ & 7.03 & 319 & 3.5 & 6.0 & 4.5 & $\begin{array}{l}5.0 \\
\text { est. }\end{array}$ & Gravel, cobble. \\
\hline 23 & $\begin{array}{l}\text { Redstone River near Ambler } \\
\left(67^{\circ} 12^{\prime} 01^{\prime \prime}, 157^{\circ} 36^{\prime} 05^{\circ}\right) \text {. }\end{array}$ & -- & 211 & 22 & 1,100 & 5.21 & 102 & 3.1 & $\begin{array}{l}4.5 \\
\text { est. }\end{array}$ & 3.5 & $\begin{array}{l}4.0 \\
\text { est. }\end{array}$ & Gravel. \\
\hline 25 & $\begin{array}{l}\text { Jade Creek near Ambler } \\
\left(67^{\circ} 10^{\prime} 49^{\prime \prime}, 158^{\circ} 07^{\prime} 47^{\prime \prime}\right) \text {. }\end{array}$ & -- & 57 & 22 & 150 & 2.63 & 48 & .95 & 1.5 & 3.2 & 3.5 & Boulder, cobble. \\
\hline 26 & $\begin{array}{l}\text { Kobuk River below Jade } \\
\text { Creek }\left(67^{\circ} 06^{\prime} 35^{\prime \prime}, 158^{\circ} 14^{\prime} 51^{\prime \prime}\right) \text {. }\end{array}$ & 153 & 6,724 & 28 & 50,800 & 7.56 & 1,530 & 9.5 & 14.5 & 3.5 & 5.0 & Not observed. \\
\hline 27 & $\begin{array}{l}\text { Akillik River above Hunt } \\
\text { River near Ambler } \\
\left(67^{\circ} 14^{\prime} 22^{\prime \prime}, 158^{\circ} 28^{\prime} 05^{\prime \prime}\right) \text {. }\end{array}$ & -- & 303 & 22 & $\begin{array}{l}3,700 \\
\text { est. }\end{array}$ & 12.2 & 150 & 6.7 & $\begin{array}{l}10.0 \\
\text { est. }\end{array}$ & 3.7 & $\begin{array}{l}5.0 \\
\text { est. }\end{array}$ & Gravel. \\
\hline 29 & $\begin{array}{l}\text { Kavet Creek at mouth near } \\
\text { Kiana }\left(67^{\circ} 07^{\prime} 24^{\prime \prime}, 159^{\circ} 01^{\prime} 30^{\prime \prime}\right) \text {. }\end{array}$ & )- & 25 & 29 & 55 & 2.20 & 42 & 1.4 & 1.8 & 1.0 & 1.2 & Sand. \\
\hline 30 & $\begin{array}{l}\text { Salmon River above Kitlik } \\
\text { River near Kiana } \\
\left(67^{\circ} 15^{\prime} 12^{\prime \prime}, 159^{\circ} 38^{\prime} 58^{\prime \prime}\right) \text {. }\end{array}$ & $-\infty$ & 515 & 23 & 4,400 & 8.54 & 390 & 2.3 & $\begin{array}{l}5.0 \\
\text { est. }\end{array}$ & 4.8 & $\begin{array}{l}6.0 \\
\text { est. }\end{array}$ & $\begin{array}{l}\text { Boulder, cobble, } \\
\text { gravel. }\end{array}$ \\
\hline 31 & $\begin{array}{l}\text { Kitlik River near Kiana } \\
\left(67^{\circ} 14^{\circ} 30^{\prime \prime}, 159^{\circ} 40^{\circ} 06^{\prime \prime}\right) \text {. }\end{array}$ & - & 98 & 23 & 851 & 8.68 & 84 & 2.7 & 5.3 & 3.8 & 5.0 & Cobble. \\
\hline
\end{tabular}


Values of the hydraulic properties measured during August 1979 are listed in table 1. Cross sections at survey sites on the Kobuk River are shown in figure 5 . The survey sites were selected to measure the variation in hydrologic and hydraulic properties along the river in reaches that had (1) uniform cross-sectional shape; (2) minimum channel bend; and (3) well-defined high-water marks to indicate the maximum evident flood. (See section on Floods and Erosion.) Elevations of the maximum evident flood surface, the bankfull channel surface, and the water surface at the time of the survey are shown on the cross sections. In August 1979 the channel of the Kobuk River from above Walker Lake outlet (site 1) to Okok Point at the head of the Kobuk River delta was fairly uniform in cross-sectional shape; that is, it was not an alternating pool-and-riffle sequence.

Stream width on the Kobuk River increased in a downstream direction from about 200 $\mathrm{ft}$ at Walker Lake outlet to $1,500 \mathrm{ft}$ near the mouth. Maximum depths increased from $3 \mathrm{ft}$ to $15 \mathrm{ft}$ in the same reach. Maximum surface velocity ranged from about $3 \mathrm{ft} / \mathrm{s}$ to $6 \mathrm{ft} / \mathrm{s}$. From Walker Lake outlet to Kobuk village the river is generally a tranquil stream and has good recreational boating conditions. The only navigation hazards were rapids at Walker Lake outlet (figs. 6 and 7) and in Lower Kobuk Canyon (figs. 8 and 9). A portage trail is on the left bank (as viewed downstream) at Walker Lake outlet rapids, but no trail exists in the Lower Kobuk Canyon. Downstream from Kobuk village, the river is wide, deep, and smooth flowing. Most reaches of the channel have gravel, cobble, or boulder bottoms (table 2), and the water is usually clear.

Table 2. -- Scale of streambed material particle sizes

\begin{tabular}{lc|c} 
Class & Millimeters & Inches \\
\hline Boulders & $>256$ & $>10$ \\
Cobbles & $256-64$ & $10-2.5$ \\
Gravel & $64-2$ & $2.5-0.078$ \\
Sand & $2-0.062$ & $0.078-0.0024$ \\
\hline \multicolumn{2}{c}{}
\end{tabular}

During the March and April 1980 survey, nine stream sites were visited. The sites are listed in downstream order in table 3, and their locations are shown in figure 10. In March, snow and ice in the Kobuk River bas in supported snow vehicles and airplanes equipped with skis. Such travel was unsafe after April 1 because snowmelt caused by afternoon sunshine infiltrated and weakened the snowpack and seeped as overflow onto ice. This unexpected change thwarted the survey party's efforts to make late winter low-flow measurements in some parts of the central and eastern Kobuk basin. However, the weather change presented an opportunity to observe changes that can occur in ice and snow conditions at the beginning of "spring breakup."

Because of the snow-melt contributions to streamflow, discharges measured in April at the Kogoluktuk River near Kobuk (site 15) and at the Kobuk River above Kobuk (site 16) may not reflect minimum winter discharges. The minimum discharges probably occurred in late March. Overflow on the Shungnak River near Shungnak (site 21) prevented the survey party from measuring discharge (fig. 11). The discharge of Canyon Creek near Kiana (site 33) was measured in an open lead (fig. 12). Downstream from the lead the creek overflowed onto a large icing (fig. 13). 


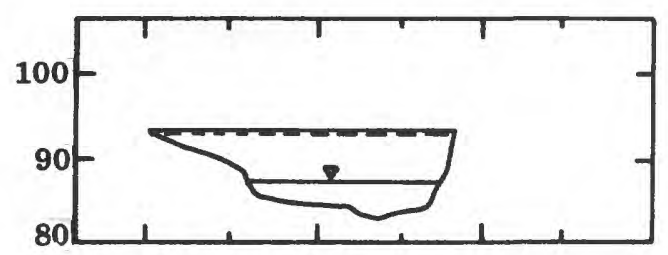

Site 1

Above Walker Lake outlet
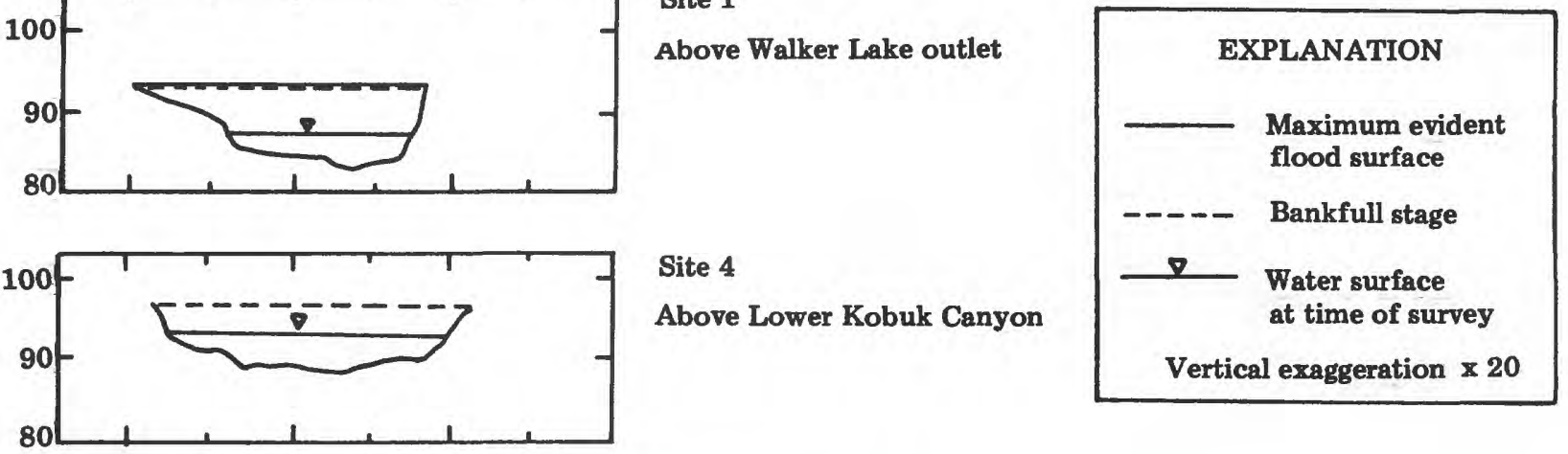

Site 4

Above Lower Kobuk Canyon

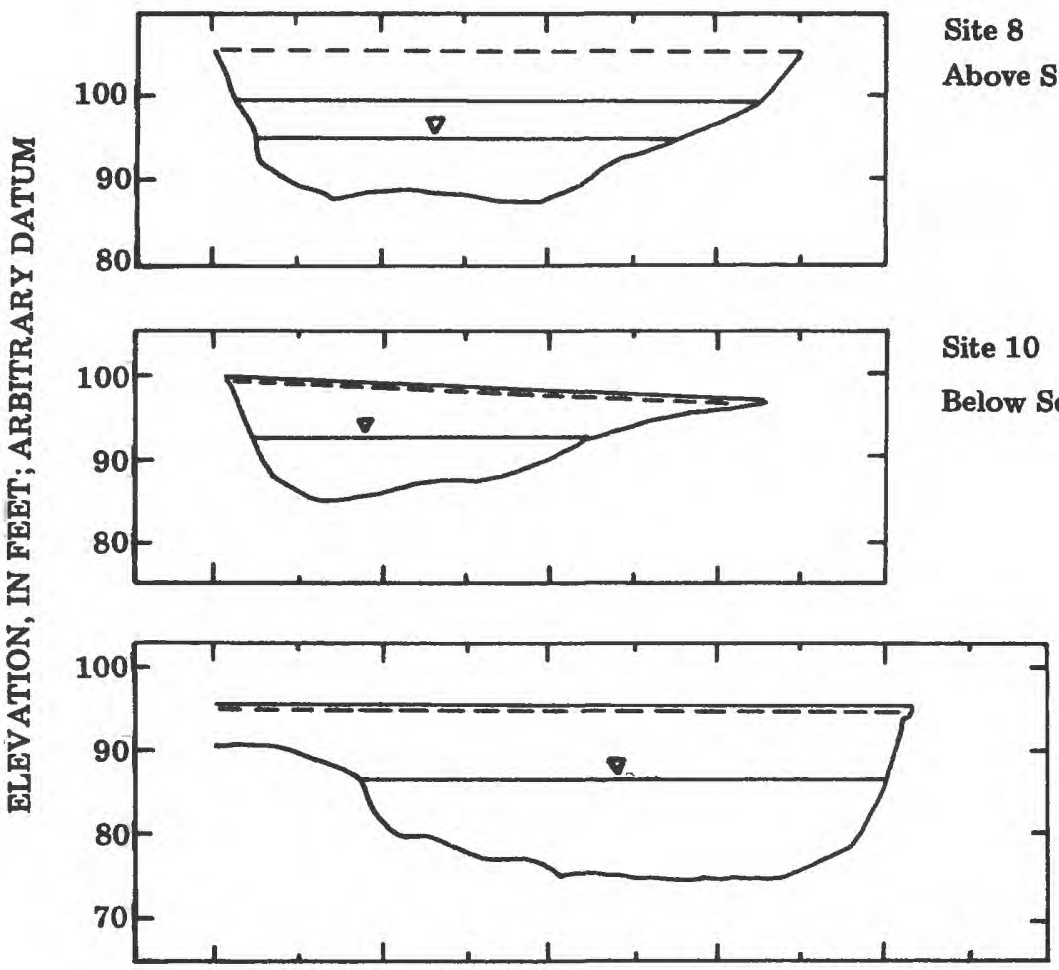

Site 16

Above Kobuk Village

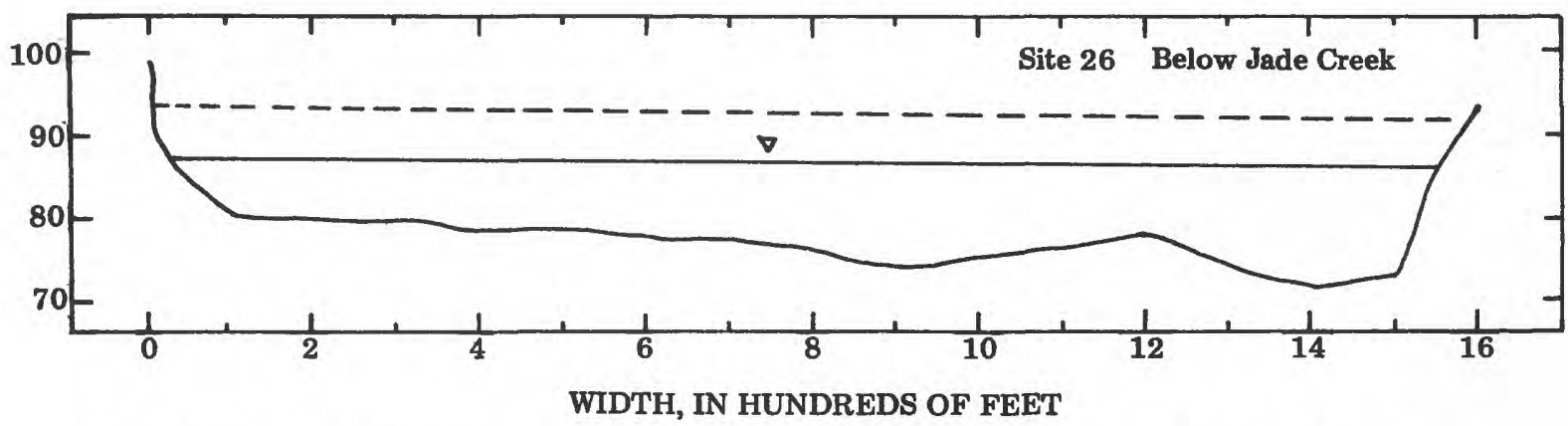

Figure 5.--Kobuk River cross sections as viewed looking downstream, August 1979. (Information about sites is given in tables 1 and 5.) 


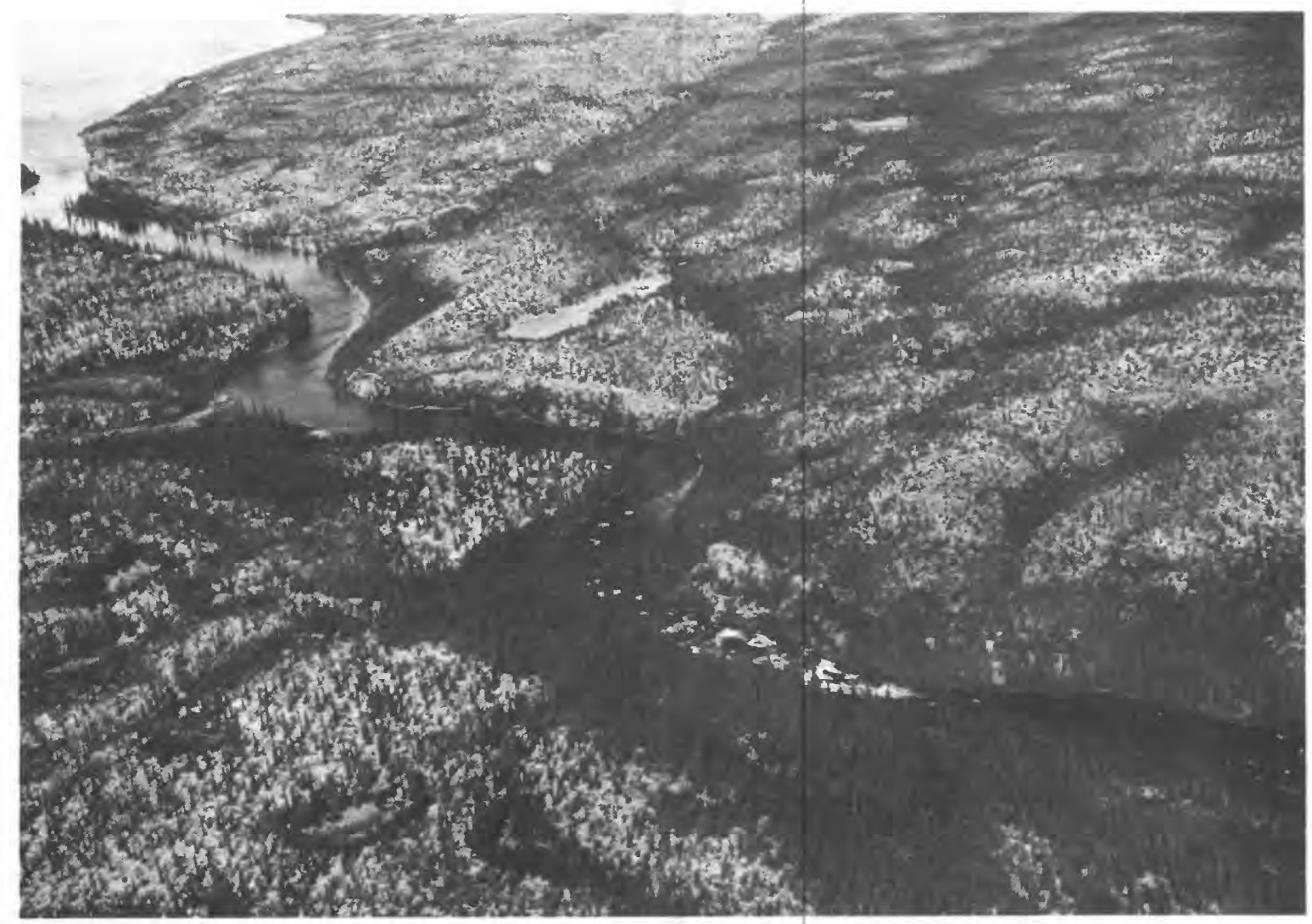

Figure 6.--Aerial photograph of Walker Lake outlet, June 1, 1979. Stream about 50 feet wide at rapids in lower center of photograph. See figure 7 for close-up of rapids.

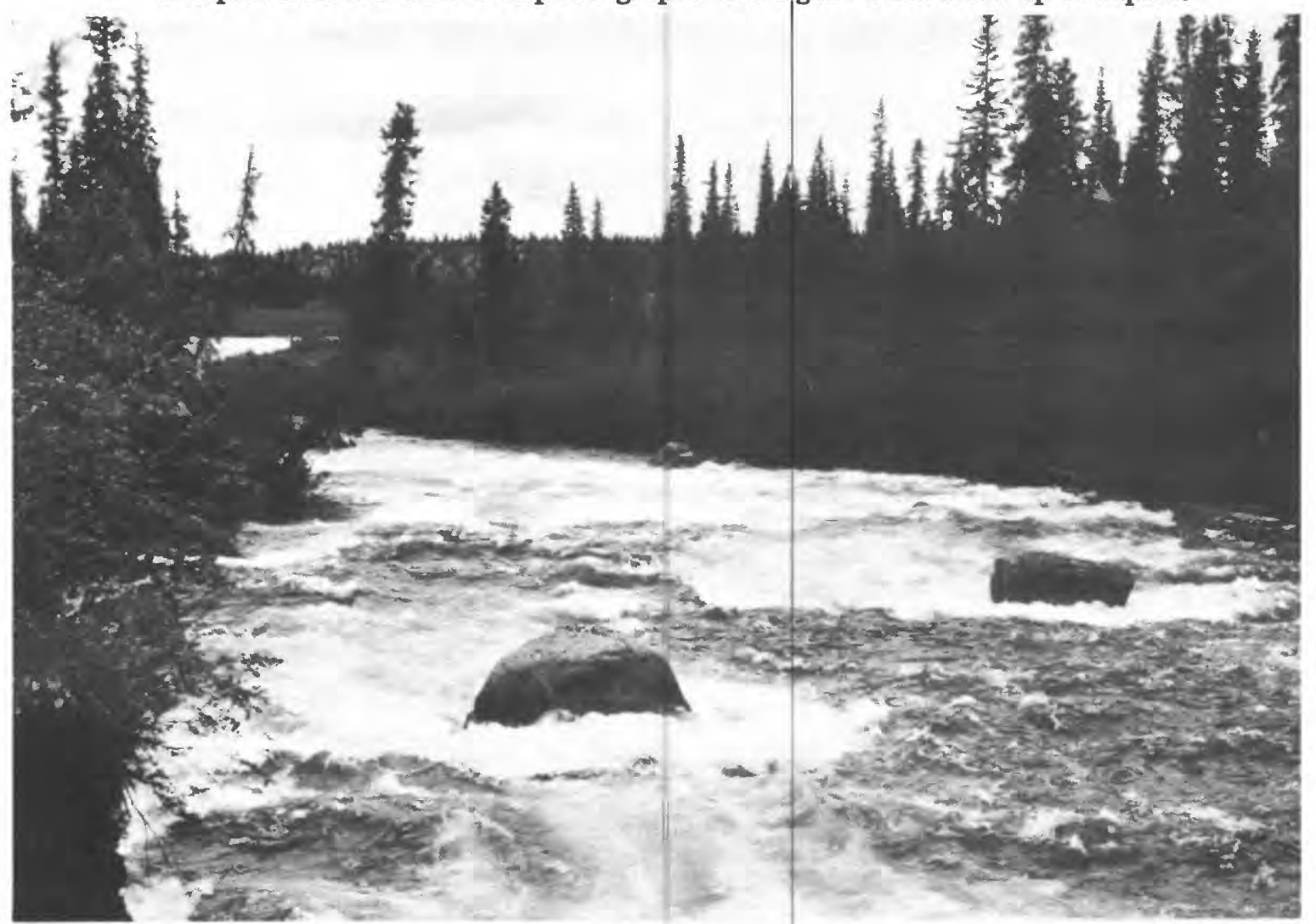

Figure 7.--Walker Lake outlet, August 11, 1979; view downstream from left bank. 


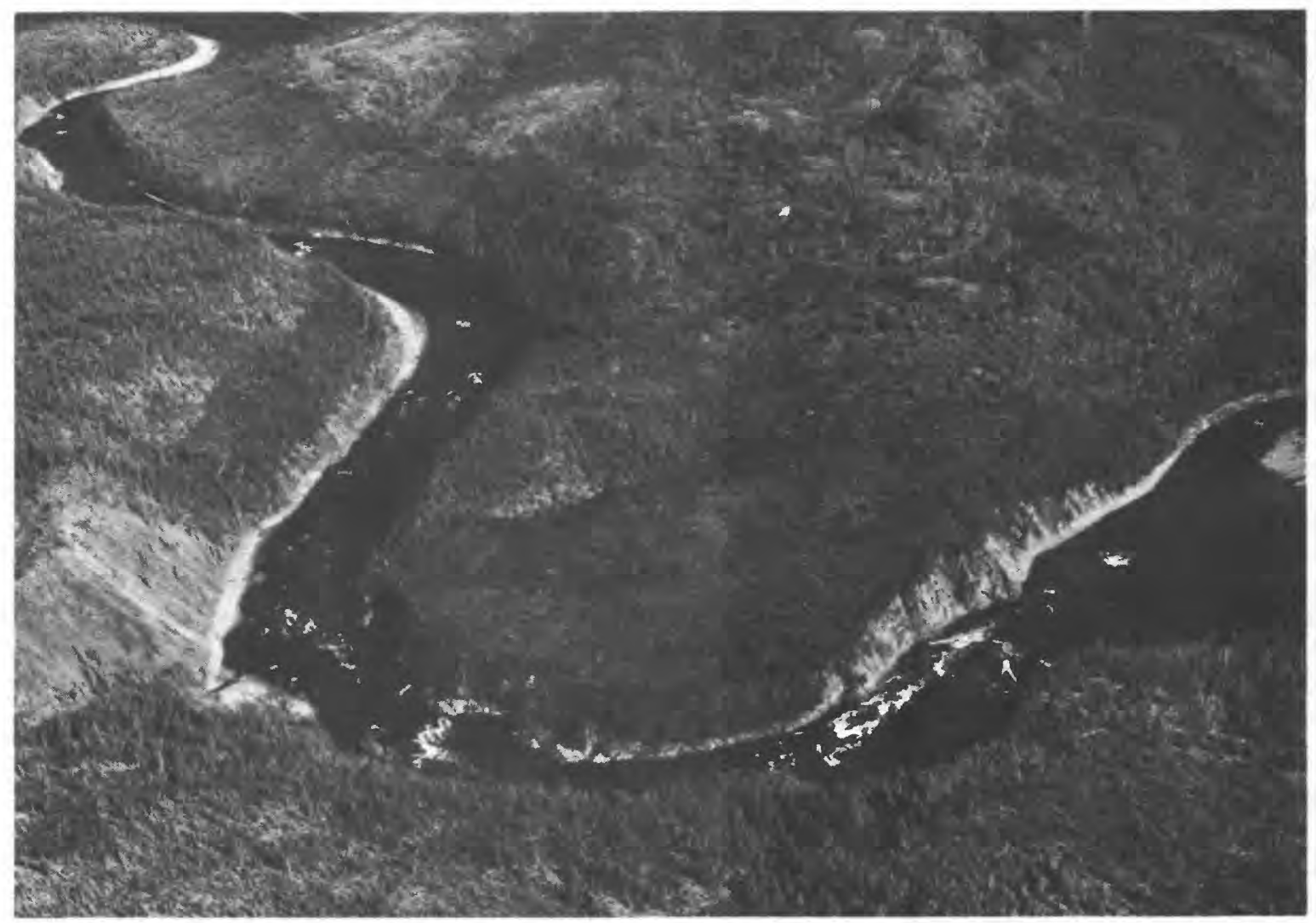

Figure 8.--Aerial photograph of Lower Kobuk Canyon rapids, June 1, 1979. Stream width about 300 feet in area of rapids, lower right-hand portion of photograph.

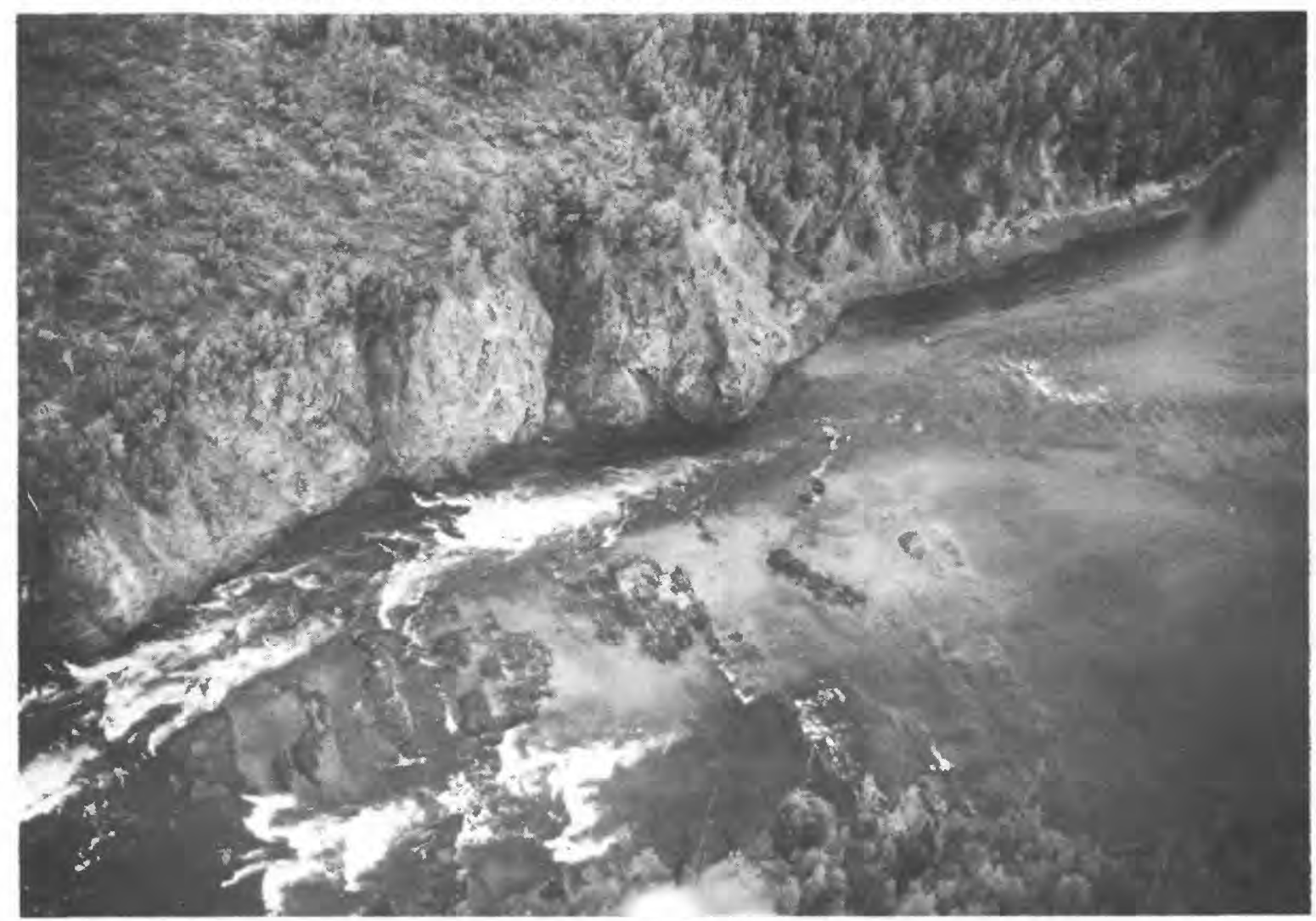

Figure 9.--Close-up aerial photograph of Lower Kobuk Canyon rapids, August 14, 1979. 


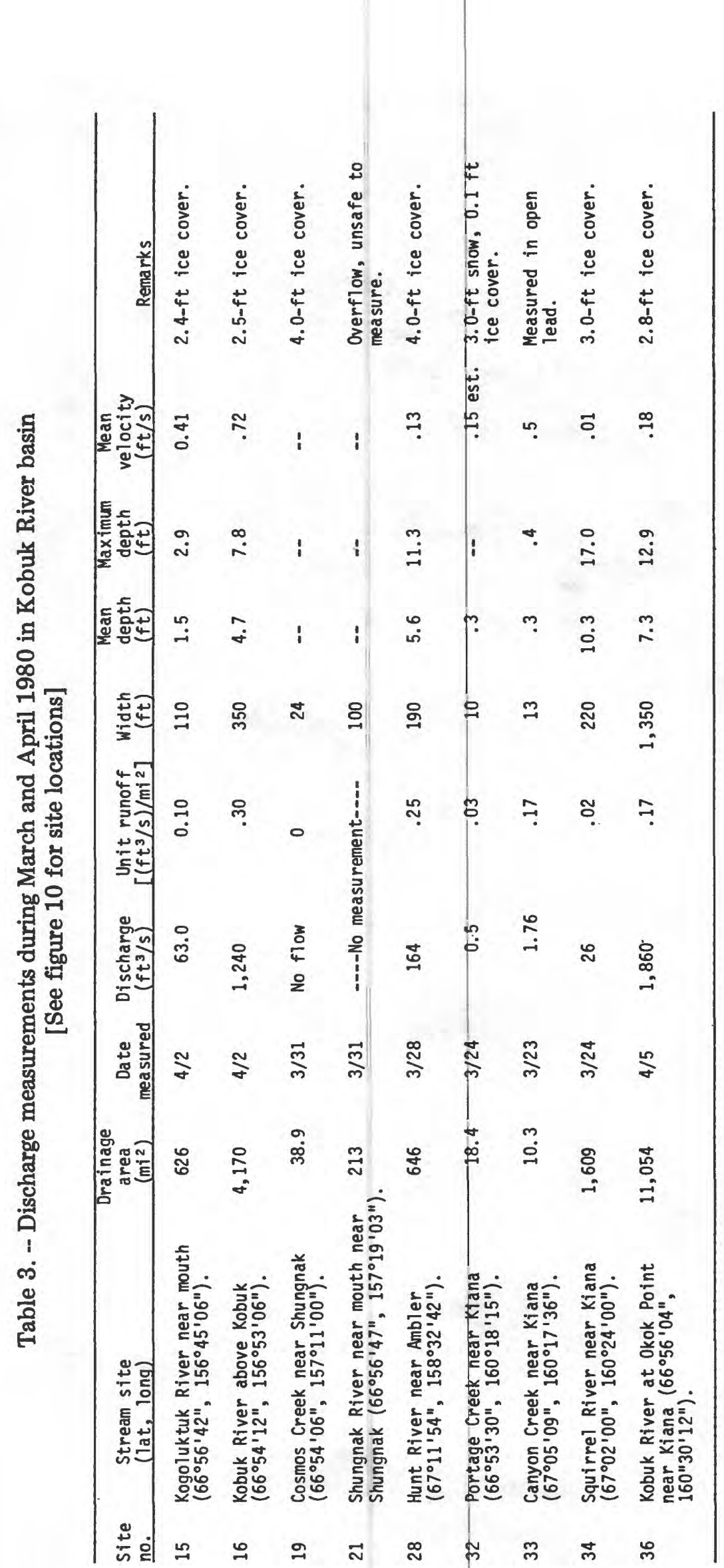




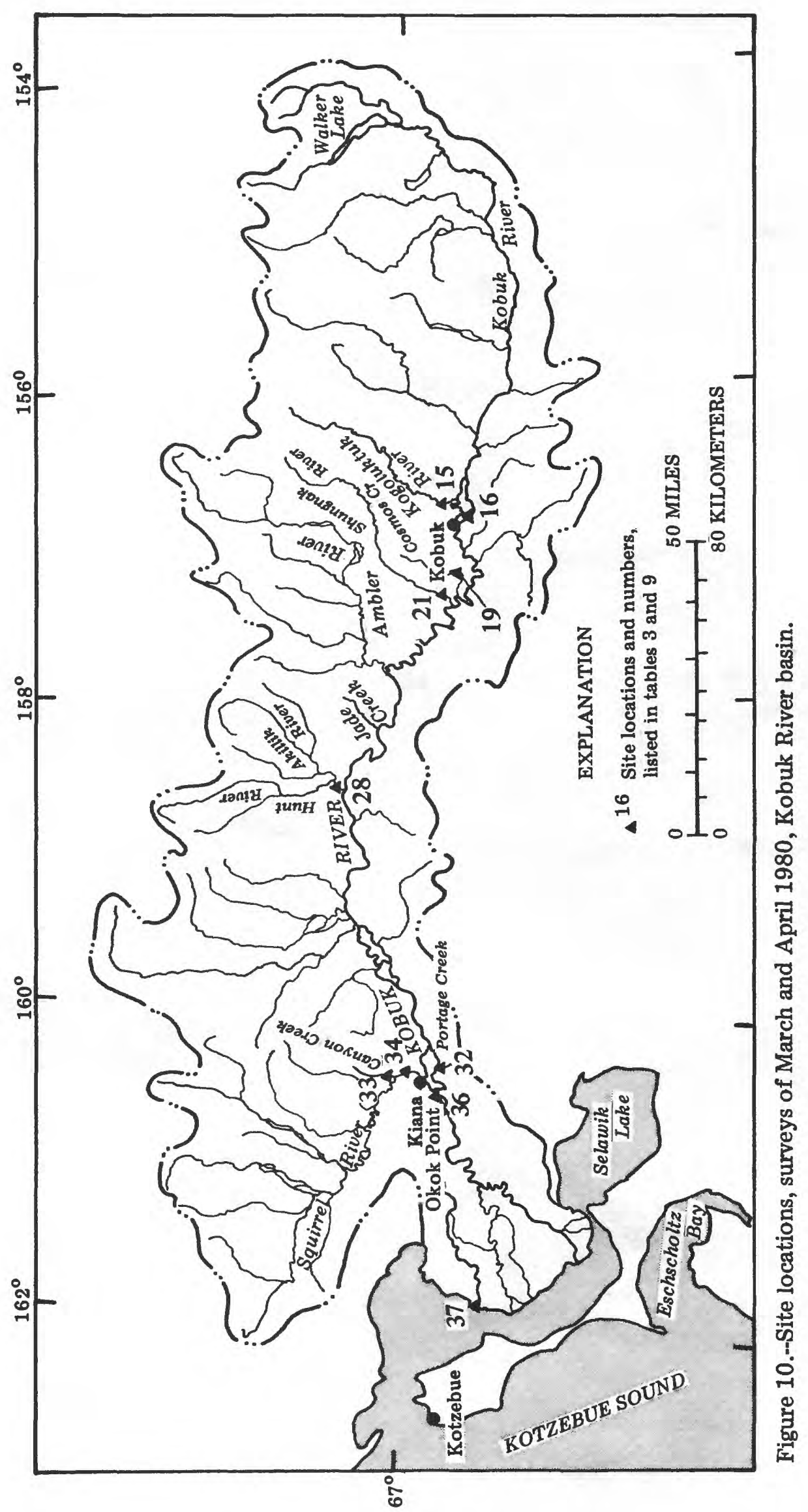




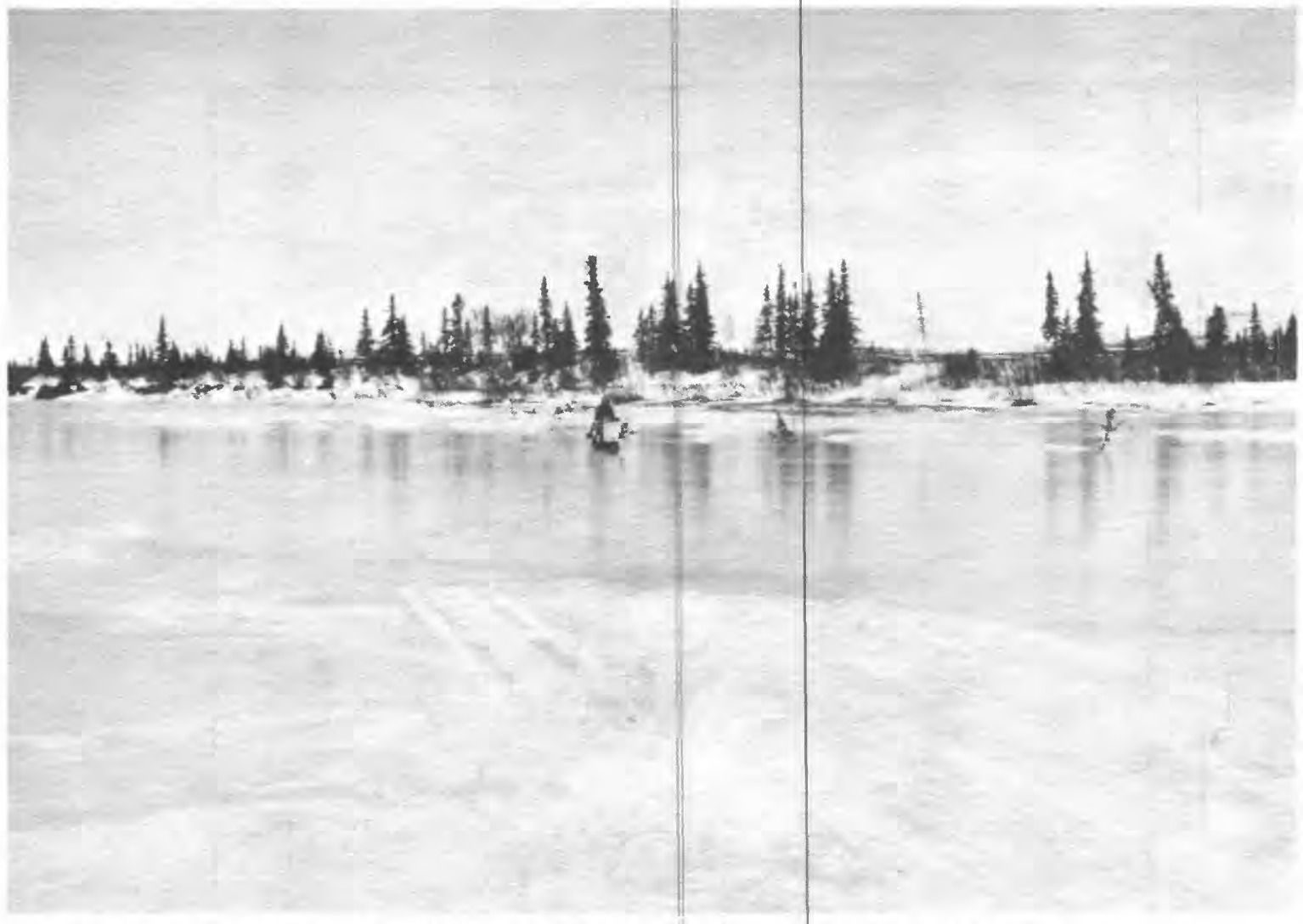

Figure 11.-Overflow ice on Shungnak River near Shungnak, April 4, 1980.

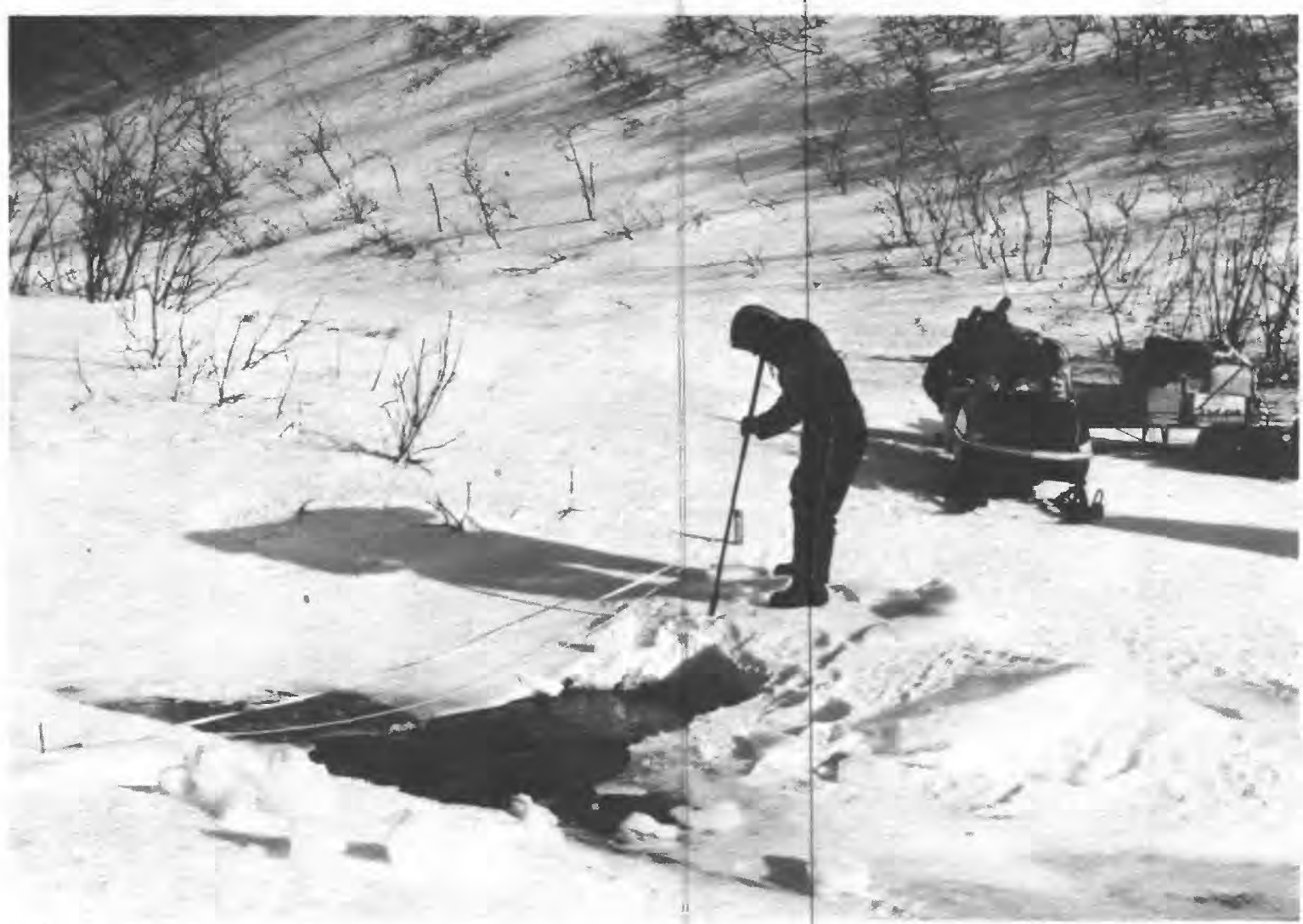

Figure 12.--Canyon Creek near Kiana at survey site, March 23, 1980. 


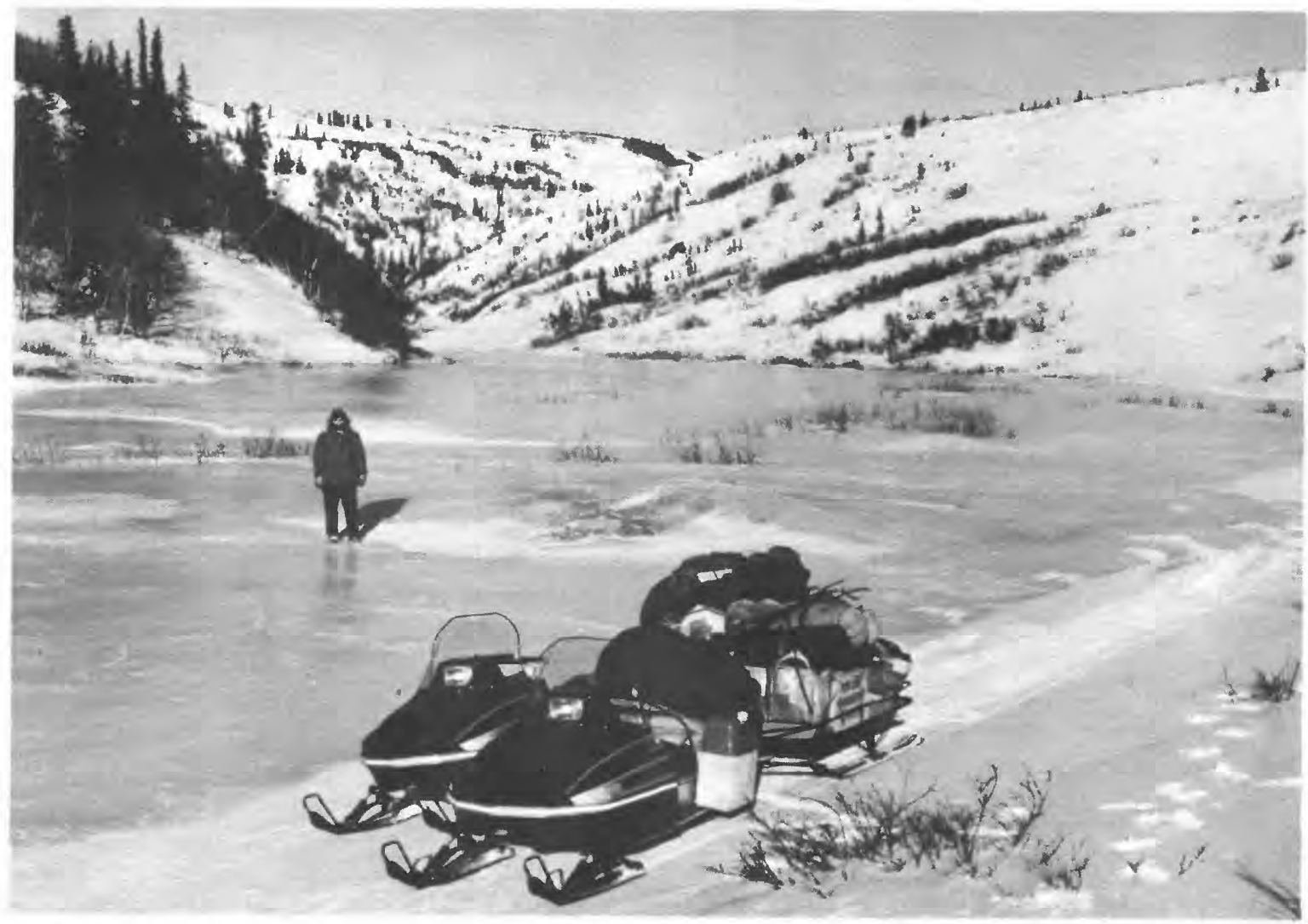

Figure 13.--Icing on Canyon Creek near Kiana, March 23, 1980.

Even though streamflow was affected by snowmelt, the late winter data indicate some areal variability of low flow in the Kobuk basin; values approaching no flow may be expected from some tributaries. For example, the measured discharge at Squirrel River near Kiana (site 34) was $26 \mathrm{ft}^{3} / \mathrm{s}$, which indicates a unit runoff of only 0.02 $\left(\mathrm{ft}^{3} / \mathrm{s}\right) / \mathrm{mi}^{2}$, and there was no apparent flow on Cosmos Creek (site 19) under $6 \mathrm{ft}$ of ice.

\section{STREAMGAGING RECORDS}

The Geological Survey operated a streamgaging station on the Kobuk River at Ambler from 1965 to 1978. Mean monthly discharge and monthly mean discharges that were exceeded in 75, 50, and 25 percent of the months during the 13-year period are shown in table 4 .

Streamflow varies greatly from one season to another. For example, the median discharge (50 percent probability) for June is nearly 27 times the median discharge for March. The ratio of 25 to 75 percent discharge, $Q_{25} / Q_{75}$, can be used to show the variability of flow within a given period or season. The ratio of 1.3 for April indicates much less variability than does the ratio of 2.5 for June. The maximum daily mean discharge at Ambler in the 13-year period of record was 95,000 $\mathrm{ft}^{3} / \mathrm{s}$, on May 29, 1971. The minimum daily mean discharge, $700 \mathrm{ft}^{3} / \mathrm{s}$, occurred Apri1 1-15, 1975. 
Table 4. - Flow characteristics of Kobuk River at Ambler.

Drainage area, 6,570 $\mathrm{mi}^{2}$; period of record, 13 years (1965-78).

Discharge values (Q) in cubic feet per second.

\begin{tabular}{|c|c|c|c|c|c|}
\hline \multirow[b]{2}{*}{ Month } & \multirow{2}{*}{$\begin{array}{l}\text { Mean monthly } \\
\text { discharge }\end{array}$} & \multicolumn{3}{|c|}{$\begin{array}{l}\text { Monthly mean discharges exceeded the } \\
\text { given percents of time }\end{array}$} & \multirow{2}{*}{$\frac{Q_{25}}{Q_{75}}$} \\
\hline & & 75 percent & 50 percent & 25 percent & \\
\hline October & 8,585 & 5,203 & 6,910 & 11,830 & 2.3 \\
\hline November & 3245 & 2,204 & 3,560 & 3,983 & 1.8 \\
\hline December & 1,904 & 1,399 & 2,000 & 2,394 & 1.7 \\
\hline January & 1,448 & 1,016 & 1,513 & 1,720 & 1.7 \\
\hline February & 1,237 & 950 & 1,152 & 1,418 & 1.5 \\
\hline March & 1,111 & 925 & 1,000 & 1,300 & 1.4 \\
\hline April & 1,155 & 976 & 1,160 & 1,304 & 1.3 \\
\hline May & 15,030 & 10,080 & 15,140 & 19,070 & 1.9 \\
\hline June & 30,900 & 18,260 & 26,640 & 45,370 & 2.5 \\
\hline July & 14,390 & 8,199 & 13,850 & 18,640 & 2.3 \\
\hline August & 15,320 & 9,127 & 11,280 & 20,700 & 2.8 \\
\hline September & 13,590 & 8,670 & 11,950 & 16,150 & 1.9 \\
\hline
\end{tabular}

Unit runoff values calculated from median monthly mean discharges at the gaging station provide a base for estimating the probability level of the miscellaneous measurements. Computed low-flow unit runoff (March) for the station is 0.15 $\left(\mathrm{ft}^{3} / \mathrm{s}\right) / \mathrm{mi}^{2}$. Late summer unit runoff (August and September) is about 1.7 $\left(\mathrm{ft}^{3} / \mathrm{s}\right) / \mathrm{mi}^{2}$. The maximum recorded unit runoff, based on recorded maximum daily discharge, is about $15\left(\mathrm{ft}^{3} / \mathrm{s}\right) / \mathrm{mi}^{2}$.

The gaging station at Ambler was discontinued in 1978. Another station, Kobuk River near Kiana, was established in 1976; the drainage area for this station is much larger than that of the Ambler station (9,520 vs. 6,570 $\mathrm{mi}^{2}$ ).

\section{FLOODS AND EROSION}

Flood hazards along a stream valley can be evaluated by studying evidence left by past floods. If large floods have occurred in the recent past (with in the last 50 year), traces of these floods can usually be recognized from accumulations of debris, washlines on steep banks, and channels swept clear of vegetation. If one assumes that future flood conditions will be similar to those in the past, potential hazards can be estimated by interpreting this evidence. The highest floodmarks at a site are indications of "maximum evident floods," or MEF, at that site. The areal extent of inundation can be determined by mapping marks by the MEF. Profiles of the water surface at flood stage can be determined by surveying MEF marks.

If the channel position and configuration have remained stable since the MEF occurred, hydraulic properties of the channel can be measured and used to compute discharge of the flood (Riggs, 1976). Computed MEF discharge is an estimate of the maximum instantaneous peak discharge that has occurred in the channel in the recent past. 
Surveys were made to measure channel geometry and, where possible, to compute MEF discharge at six sites along the Kobuk River and on 15 tributaries (fig. 4 and table 5). Some of the sites had evidence of ice-affected floods (table 5). If the floodmarks were adequate to define the water-surface profile, MEF discharge was computed even though unknown ice conditions may have caused significant backwater at the site during the flood. If significant backwater were present, computed MEF discharge would be higher than the true discharge.

Along the Kobuk River, computed MEF discharge ranged from $22,600 \mathrm{ft}^{3} / \mathrm{s}$ above Walker Lake outlet to $71,700 \mathrm{ft}^{3} / \mathrm{s}$ at Kobuk. MEF unit runoff calculated from those discharges ranged from $79.3\left(\mathrm{ft}^{3} / \mathrm{s}\right) / \mathrm{mi}^{2}$ above Walker Lake outlet (site 1 ) to 15.7 $\left(\mathrm{ft}^{3} / \mathrm{s}\right) / \mathrm{mi}^{2}$ below Selby River (site 10). At all survey sites along Kobuk River and its tributaries, MEF unit runoff was less than $100\left(\mathrm{ft}^{3} / \mathrm{s}\right) / \mathrm{mi}^{2}$; for drainage areas larger than $1,000 \mathrm{mi}^{2}$ it was less than $25\left(\mathrm{ft}^{3} / \mathrm{s}\right) / \mathrm{mi}^{2}$. No MEF discharge was computed for the gaging station at Ambler. However, the maximum daily mean discharge recorded at the site, $95,000 \mathrm{ft}^{3} / \mathrm{s}$, yields a unit runoff of $14.5\left(\mathrm{ft}^{3} / \mathrm{s}\right) / \mathrm{mi}^{2}$.

Channel hydraulic geometry and computed discharge at bankfull stage are indicated in table 5. At most survey sites one or more unvegetated channels were bounded by grassy or brush-covered sloping banks and overbank areas covered with trees, brush, or tundra. Spruce and poplar trees and willow shrubs were common on the flood plain along the Kobuk River and its tributaries. Bankfull elevations were determined by observing the flood-plain surface (Leopold and Skibitzke, 1967) and the edge of mature flood-plain forest or vegetation (Sigafoos, 1964). Bankfull surface elevations ranged from about $5 \mathrm{ft}$ to more than $10 \mathrm{ft}$ higher than the water surface at the time of the surveys along the Kobuk River (fig. 5) and most of its tributaries. At the sites on lake outlets, bankfull elevations ranged from less than 1 $\mathrm{ft}$ to a little over $2 \mathrm{ft}$ higher than the water surface. At most sites the stage of the MEF was approximately the same as bankfull stage; therefore bankfull stage appears to be a usable parameter for assessing flood hazards in the Kobuk River basin.

Lamke (1979) found that three conditions or characteristics of a drainage basin -drainage area, percent of area covered by forests, and percent of area covered by lakes and ponds -- have a significant effect on the flood characteristics of Alaskan streams. Values of those drainage basin characteristics applicable to the survey sites in the Kobuk River basin are shown in table 5 . Discharges for the 2-year flood $\left(Q_{2}\right)$ and the 50-year flood $\left(Q_{50}\right)$ were computed for the flood survey sites from these drainage basin characteristics, using multiple regression equations developed by Lamke (table 5). A $Q_{2}$ flood discharge has a 50 percent change of being exceeded in a particular year; a $Q_{50}$ flood discharge has a 2 percent chance of being exceeded. The $Q_{2}$ and $Q_{50}$ flood estimates, as well as the MEF discussed above, are subject to substantial errors.

Vegetation generally protects soils from erosion. However, many bare, high banks in the Kobuk River valley are composed of silty sands that are easily eroded during brief periods of high water. Melting of exposed permafrost can also cause erosion. When the soil-ice mass thaws, it is weakened and easily eroded by flowing water, or it may slump, sometimes as large chunks. During the August 1979 survey, the Kobuk River channel appeared to be stable at the surveyed sites and throughout most of its length. However, slumping banks and exposed ice masses were observed near Shungnak (fig. 14). 
Table 5. - Bankfull channel, maximum evident flood, basin, and flood characteristics at flood survey sites in the Kobuk River basin, 1979

\begin{tabular}{|c|c|c|c|c|c|c|c|c|c|c|c|c|c|c|c|}
\hline \multirow[b]{2}{*}{$\begin{array}{l}\text { Site } \\
\text { no. }\end{array}$} & \multirow[b]{2}{*}{$\begin{array}{l}\text { Stream site } \\
\text { (lat, long) }\end{array}$} & \multirow[b]{2}{*}{$\begin{array}{l}\text { Streambed } \\
\text { material }\end{array}$} & \multirow{2}{*}{$\begin{array}{l}\text { Water } \\
\text { surface } \\
\text { slope } \\
(\mathrm{ft} / \mathrm{ft})\end{array}$} & \multicolumn{4}{|c|}{ Bankfull channel } & \multicolumn{3}{|c|}{ Maximum evident flood } & \multicolumn{3}{|c|}{ Basin characteristics* } & \multicolumn{2}{|c|}{ Flood characteristics $\left(\mathrm{ft}^{3} / \mathrm{s}\right)$} \\
\hline & & & & $\begin{array}{l}\text { Width } \\
(\mathrm{ft})\end{array}$ & $\begin{array}{l}\text { Mean } \\
\text { depth } \\
\text { (ft) }\end{array}$ & $\begin{array}{l}\text { Max. } \\
\text { depth } \\
(\mathrm{ft})\end{array}$ & $\begin{array}{c}\text { Discharge, } \\
\text { computed } \\
\left(\mathrm{ft}^{3} / \mathrm{s}\right)\end{array}$ & $\begin{array}{l}\text { Width } \\
(\mathrm{ft})\end{array}$ & $\begin{array}{l}\text { Discharge, } \\
\text { computed } \\
\left(\mathrm{ft}^{3} / \mathrm{s}\right)\end{array}$ & $\begin{array}{l}\text { Unit runoff } \\
{\left[\left(\mathrm{ft}^{3} / \mathrm{s}\right) / \mathrm{mi}^{2}\right]}\end{array}$ & $\begin{array}{c}\text { Drainage } \\
\text { area } \\
\left(m i^{2}\right)\end{array}$ & $\begin{array}{c}\text { Forests } \\
\text { area } \\
\text { (percent) }\end{array}$ & $\begin{array}{l}\text { Lakes and } \\
\text { ponds area } \\
\text { (percent) }\end{array}$ & $\begin{array}{c}Q_{2} \\
(2-y r \text { flood }) \\
\end{array}$ & $\begin{array}{c}Q_{50} \\
(50-y r \text { flood })\end{array}$ \\
\hline 1 & $\begin{array}{l}\text { Kobuk River above walker } \\
\text { Lake out Tet. } \\
\left(67^{\circ} 01^{\prime} 37^{\prime \prime}, 154^{\circ} 20^{\prime} 36^{\prime \prime}\right) \text {. }\end{array}$ & $\begin{array}{l}\text { Cobble, } \\
\text { gravel. }\end{array}$ & 0.0024 & 367 & 6.6 & 10.3 & 22,600 & 367 & a 22,600 & 79.3 & 285 & 43.2 & 0 & 3,820 & 12,000 \\
\hline 2 & $\begin{array}{l}\text { Walker Lake outlet } \\
\left(67^{\circ} 03^{\prime} 29^{\prime \prime}, 154^{\circ} 18^{\prime} 49^{\prime \prime}\right) \text {. }\end{array}$ & $\begin{array}{l}\text { Boulders, } \\
\text { gravel, } \\
\text { sand. }\end{array}$ & $.001 B$ & 207 & 4.1 & 6.6 & 5,000 & 207 & 5,000 & 28.1 & 178 & 23.9 & 8.7 & 1,750 & 5,740 \\
\hline 3 & $\begin{array}{l}\text { Nutuvukti Lake outlet } \\
\left(66^{\circ} 57^{\prime} 19^{\prime \prime}, 154^{\circ} 35^{\prime} 50^{\prime \prime}\right) .\end{array}$ & $\begin{array}{l}\text { Gravel, } \\
\text { sand. }\end{array}$ & .00016 & 32 & 2.4 & 3.2 & 70 & b & -- & -- & 29 & 59.3 & 22.2 & 240 & 983 \\
\hline 4 & $\begin{array}{l}\text { Kobuk River above Lower } \\
\text { Kobuk Canyon } \\
\left(66^{\circ} 50^{\prime} 06^{\prime \prime}, 154^{\circ} 39^{\prime} 00^{\prime \prime}\right) \text {. }\end{array}$ & $\begin{array}{l}\text { Cobble, } \\
\text { gravel, } \\
\text { sand. }\end{array}$ & .0096 & 391 & 5.9 & 8.2 & 15,000 & 391 & - & - & 714 & 47.0 & 4.2 & 6,530 & 18,000 \\
\hline 6 & $\begin{array}{l}\text { Reed River near mouth } \\
\left(66^{\circ} 49^{\prime} 25^{\prime \prime}, 154^{\circ} 57^{\prime} 31^{\prime \prime}\right) \text {. }\end{array}$ & $\begin{array}{l}\text { Gravel, } \\
\text { sand. }\end{array}$ & .00067 & 300 & 6.1 & 8.0 & 9,500 & 300 & a 9,500 & 26.1 & 364 & 34.5 & 1.2 & 4,280 & 13,000 \\
\hline 8 & $\begin{array}{l}\text { Kobuk River above } \\
\text { Sulakpoatokvik Creek } \\
\left(66^{\circ} 46^{\prime} 36^{\prime \prime}, 155^{\circ} 10^{\prime} 18^{\prime \prime}\right) .\end{array}$ & $\begin{array}{l}\text { Cobble, } \\
\text { gravel. }\end{array}$ & .00074 & 700 & 13.3 & 18.1 & 86,900 & 624 & a 36,600 & 23.5 & 1,560 & 49.2 & 3.3 & 14,000 & 34,700 \\
\hline 9 & $\begin{array}{l}\text { Lake Selby outlet } \\
\left(66^{\circ} 51^{\prime} 04^{\prime \prime}, 155^{\circ} 41^{\prime} 04^{\prime \prime}\right) .\end{array}$ & $\begin{array}{l}\text { Boulder, } \\
\text { cobble, } \\
\text { gravel. }\end{array}$ & .00030 & 290 & 2.5 & 3.7 & 2,000 & 290 & 2,000 & 17.7 & 113 & 37.0 & 11.1 & 1,030 & 3,580 \\
\hline 10 & $\begin{array}{l}\text { Kobuk River below Selby } \\
\text { River } \\
\left(66^{\circ} 46^{\prime} 18^{\prime \prime}, 155^{\circ} 50^{\prime} 00^{\prime \prime}\right) .\end{array}$ & $\begin{array}{l}\text { Cobble, } \\
\text { gravel. }\end{array}$ & .00047 & 659 & 7.5 & 14.0 & 31,300 & 659 & 31,300 & 15.7 & 2,000 & 54.1 & 3.4 & 18,700 & 41,600 \\
\hline 11 & $\begin{array}{l}\text { Pah River near mouth } \\
\left(66^{\circ} 44^{\prime} 30^{\prime \prime}, 156^{\circ} 03^{\prime} 48^{\prime \prime}\right)\end{array}$ & do. & .00023 & 296 & 7.8 & 11.2 & 8,500 & 296 & 8,500 & 8.9 & 956 & 71.4 & 10.1 & 7,010 & 18,400 \\
\hline 13 & $\begin{array}{l}\text { Mauneluk River near mouth } \\
\left(66^{\circ} 52^{\circ} 40^{\prime \prime}, 156^{\circ} 16^{\prime} 45^{\prime \prime}\right) \text {. }\end{array}$ & $\begin{array}{l}\text { Boulder, } \\
\text { cobble, } \\
\text { gravel. }\end{array}$ & .00098 & 493 & 8.6 & 13.2 & 34,400 & 493 & 34,400 & 60.0 & 573 & 26.2 & 0 & 7,870 & 22,700 \\
\hline 15 & $\begin{array}{l}\text { Kogoluktuk River near } \\
\text { mouth } \\
\left(66^{\circ} 56^{\prime} 42^{n}, 156^{\circ} 45^{\prime} 06^{\prime \prime}\right) \text {. }\end{array}$ & $\begin{array}{l}\text { Boulder, } \\
\text { cobble. }\end{array}$ & .00192 & 354 & 8.7 & 11.1 & 29,000 & 354 & a 35,000 & 55.9 & 626 & 35.1 & 2.6 & 6,450 & 18,100 \\
\hline 16 & $\begin{array}{l}\text { Kobuk River above Kobuk } \\
\left(66^{\circ} 54^{\prime} 12^{\prime \prime}, 156^{\circ} 53^{\prime} 06^{\prime \prime}\right) \text {. }\end{array}$ & $\begin{array}{l}\text { Cobbie, } \\
\text { gravet. }\end{array}$ & .00021 & 833 & 14.5 & 20.6 & 71,700 & 833 & a 71,700 & 17.2 & 4,170 & 50.2 & 4.7 & 33,000 & 72,200 \\
\hline 20 & $\begin{array}{l}\text { Ruby Creek at Bornite } \\
\left(67^{\circ} \mathrm{D} 4^{\prime} 36^{\prime \prime}, 156^{\circ} 56^{\prime} 12^{\prime \prime}\right) .\end{array}$ & do. & .0054 & 53 & 2.7 & 4.1 & 690 & 53 & 690 & 53.1 & 13 & 69.2 & 0 & 200 & 935 \\
\hline 21 & $\begin{array}{l}\text { Shungnak River near mouth } \\
\text { near Shungnak } \\
\left(66^{\circ} 56^{\prime} 47^{\prime \prime}, 157^{\circ} 19^{\prime} 03^{\prime \prime}\right) \text {. }\end{array}$ & $\begin{array}{l}\text { Boulder, } \\
\text { cobble. }\end{array}$ & .00261 & 213 & 5.6 & 8.0 & 8,900 & 213 & 8,900 & 41.8 & 213 & 31.4 & 0 & 3,050 & 9,960 \\
\hline 22 & $\begin{array}{l}\text { Ambler River above } \\
\text { Redstone River } \\
\left(67^{\circ} 09^{\prime} 18^{\prime \prime}, 157^{\circ} 32^{\prime} 23^{\prime \prime}\right) \text {. }\end{array}$ & $\begin{array}{l}\text { Cobble, } \\
\text { gravel. }\end{array}$ & .00126 & 435 & 8.2 & 12.4 & 30,000 & 435 & 30,000 & 41.9 & 716 & 39.9 & .6 & 8,360 & 23,300 \\
\hline 23 & $\begin{array}{l}\text { Redstone River near Ambler } \\
\left(67^{\circ} 12^{\prime} 01^{\prime \prime}, 157^{\circ} 36^{\prime} 05^{\prime \prime}\right) \text {. }\end{array}$ & Gravel. & .00069 & 145 & 5.6 & 7.8 & 3,300 & 145 & a 3,300 & 15.6 & 211 & 22.2 & 3.7 & 2,370 & 7,670 \\
\hline 25 & $\begin{array}{l}\text { Jade Creek near Ambler } \\
\left(67^{\circ} 10^{\prime} 49^{\prime \prime}, 158^{\circ} 07^{\prime} 47^{\prime \prime}\right) \text {. }\end{array}$ & $\begin{array}{l}\text { Boulder, } \\
\text { cobble. }\end{array}$ & .0082 & 60 & 3.2 & 4.1 & 1,100 & b & -- & -- & 57 & 38.1 & 0 & 866 & 3,350 \\
\hline 26 & $\begin{array}{l}\text { Kobuk River below Jade } \\
\text { Creek } \\
\left(67^{\circ} 06^{\prime} 35^{\prime \prime}, 158^{\circ} 14^{\prime} 51^{\prime \prime}\right) \text {. }\end{array}$ & $\begin{array}{l}\text { Not } \\
\text { observed. }\end{array}$ & .00006 & 1,585 & 14.2 & 19.7 & 88,000 & - & -- & -- & 6,724 & 44.0 & 4.7 & 52,600 & 108,000 \\
\hline 27 & $\begin{array}{l}\text { Akillik River above Hunt } \\
\text { River near Ambler } \\
\left(67^{\circ} 14^{\prime} 22^{\prime \prime}, 158^{\circ} 28^{\prime} 05^{\prime \prime}\right) \text {. }\end{array}$ & GraveI. & .000415 & 377 & 7.2 & 15.3 & 10,200 & 377 & 12,600 & 41.6 & 303 & 28.4 & 1.4 & 3,640 & 11,300 \\
\hline 30 & $\begin{array}{l}\text { Salmon River above Kitlik } \\
\text { River near Kiana } \\
\left(67^{\circ} 15^{\prime} 12^{\prime \prime}, 159^{\circ} 38^{\prime} 58^{n}\right) \text {. }\end{array}$ & $\begin{array}{l}\text { Boulder, } \\
\text { cobble, } \\
\text { gravel. }\end{array}$ & .00196 & 650 & 3.7 & 8.1 & 20,900 & 530 & 19,900 & 38.6 & 515 & 36.0 & .7 & 6,170 & 17,900 \\
\hline 31 & $\begin{array}{l}\text { Kitlik River near Kiana } \\
\left(67^{\circ} 14^{\circ} 30^{\prime \prime}, 159^{\circ} 40^{\prime} 06^{\prime \prime}\right) \text {. }\end{array}$ & Cobble. & .00153 & 245 & 2.2 & 7.9 & 2,600 & 245 & 2,600 & 26.5 & 98 & 53.9 & 0 & 1,370 & 4,920 \\
\hline
\end{tabular}

* Mean annual precipitation for all sites was 20 inches, and mean minimum January temperature was $-16^{\circ} \mathrm{F}$

a Ice flood evidence. 

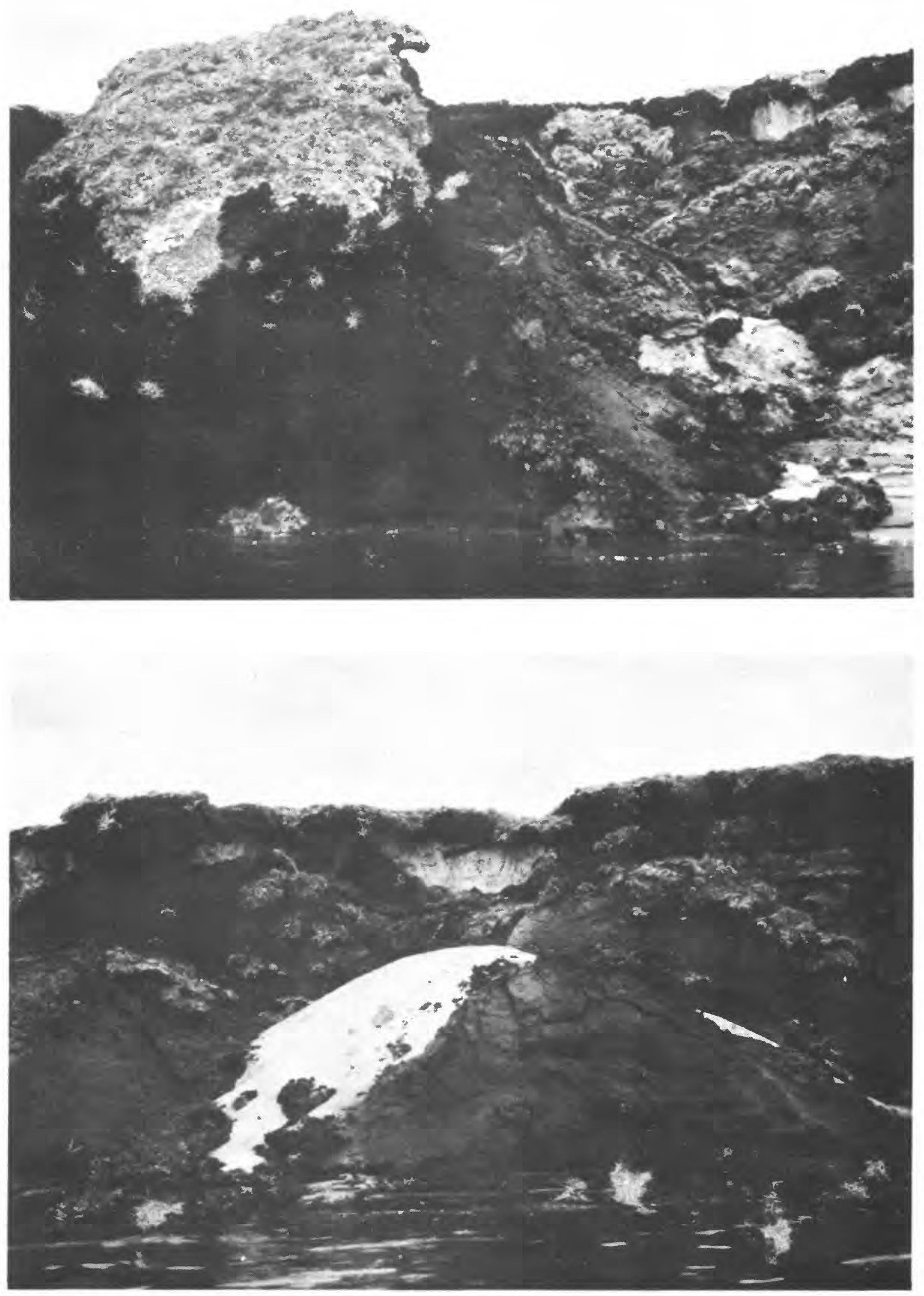

Figure 14.--Bank erosion and ice in bank along Kobuk River near Shungnak, August 26, 1979. Banks shown are about $\mathbf{1 5}$ feet high. 


\section{WATER QUALITY}

Several readily measured properties -- specific conductance, dissolved oxygen concentration, temperature, alkalinity, and $\mathrm{pH}$-- indicate the general suitability of water for various uses. Field determinations of these properties of the surface waters of the Kobuk River basin were made during both reconnaissance trips in this study. Samples were collected for laboratory analysis during the August trip. Specific conductance, or the ability of water to conduct electrical current, is an indicator of the dissolved mineral concentration. The $\mathrm{pH}$ of water is defined as the logarithm of the reciprocal of the concentration of free hydrogen ions and is thus an indicator of the acidity or basicity of the water. The pH affects aquatic organisms because it regulates the solubility and toxicity of many constituents in water. Water temperature and dissolved oxygen content are also vitally important in determining suitability of an aquatic habitat for fish, benthic invertebrates, and other organisms.

Prior to this study, water-quality data were collected on the Kobuk River at the village of Shungnak, and at the gaging stations at Ambler and near Kiana. Data from the Ambler and Kiana sites are shown in tables 6 and 7.

\section{Late Summer Samples}

Water samples were collected at 30 sites in the Kobuk River basin during August 1979 (fig. 4): 10 sites on the Kobuk River, 14 sites on tributary streams, 5 near lake outlets, and 1 at a thermal spring. Laboratory analyses for major inorganic ions were made of samples from four of the sites on the Kobuk River and from nine other sites in the basin (table 8); the analyses show that surface waters in the Kobuk River basin are predominantly calcium bicarbonate type.

August water temperatures in the Kobuk River ranged from $8.5^{\circ} \mathrm{C}$ at Ambler to $14.0^{\circ} \mathrm{C}$ above Lower Kobuk Canyon. Temperatures in tributaries ranged from $6.5^{\circ} \mathrm{C}$ at Jade Creek to $13.5^{\circ} \mathrm{C}$ at Pah River. Stream sites near lake outlets had the warmest water; these temperatures ranged from $13.5^{\circ} \mathrm{C}$ at Kollioksak Lake to $17.5^{\circ} \mathrm{C}$ at Nutuvukti Lake. Water temperature at Reed River Hot Spring was $47.5^{\circ} \mathrm{C}$.

Dissolved oxygen (DO) concentrations were measured at 18 sites at and downstream from the mouth of the Killak River. Concentrations on the Kobuk River ranged from $10.8 \mathrm{mg} / \mathrm{L}$ at two sites to $11.6 \mathrm{mg} / \mathrm{L}$. Concentrations of DO in tributaries ranged from $11.3 \mathrm{mg} / \mathrm{L}$ in Kavet Creek to $13.5 \mathrm{mg} / \mathrm{L}$ in the Killak River. A comparatively low $7.5 \mathrm{mg} / \mathrm{L}$ DO was measured at the outlet of Kollioksak Lake.

The $\mathrm{pH}$ of the Kobuk River ranged from 7.3 above Sulakpoatokvik Creek and both above and below Kobuk village to 7.9 above Lower Kobuk Canyon. The pH of the tributaries ranged from 6.5 in the Killak and Kitlik Rivers to 7.9 in the Ambler River. Lake outlet water had $\mathrm{pH}$ values similar to that of the tributaries.

The alkalinity of water in the Kobuk River ranged from $53 \mathrm{mg} / \mathrm{L}$ as $\mathrm{CaCO}_{3}$ above Sulakpoatokvik Creek to $97 \mathrm{mg} / \mathrm{L}$ as $\mathrm{CaCO}_{3}$ at the village of Kiana. Concentrations in tributaries ranged from $14 \mathrm{mg} / \mathrm{L}$ in the Kitlik River near Kiana to $117 \mathrm{mg} / \mathrm{L}$ in Kavet Creek. Lake-outlet water had concentrations mostly near $24 \mathrm{mg} / \mathrm{L}$, but alkalinity at Walker Lake outlet was $60 \mathrm{mg} / \mathrm{L}$. Water at Reed River Hot Spring had an alkalinity of $313 \mathrm{mg} / \mathrm{L}$. 


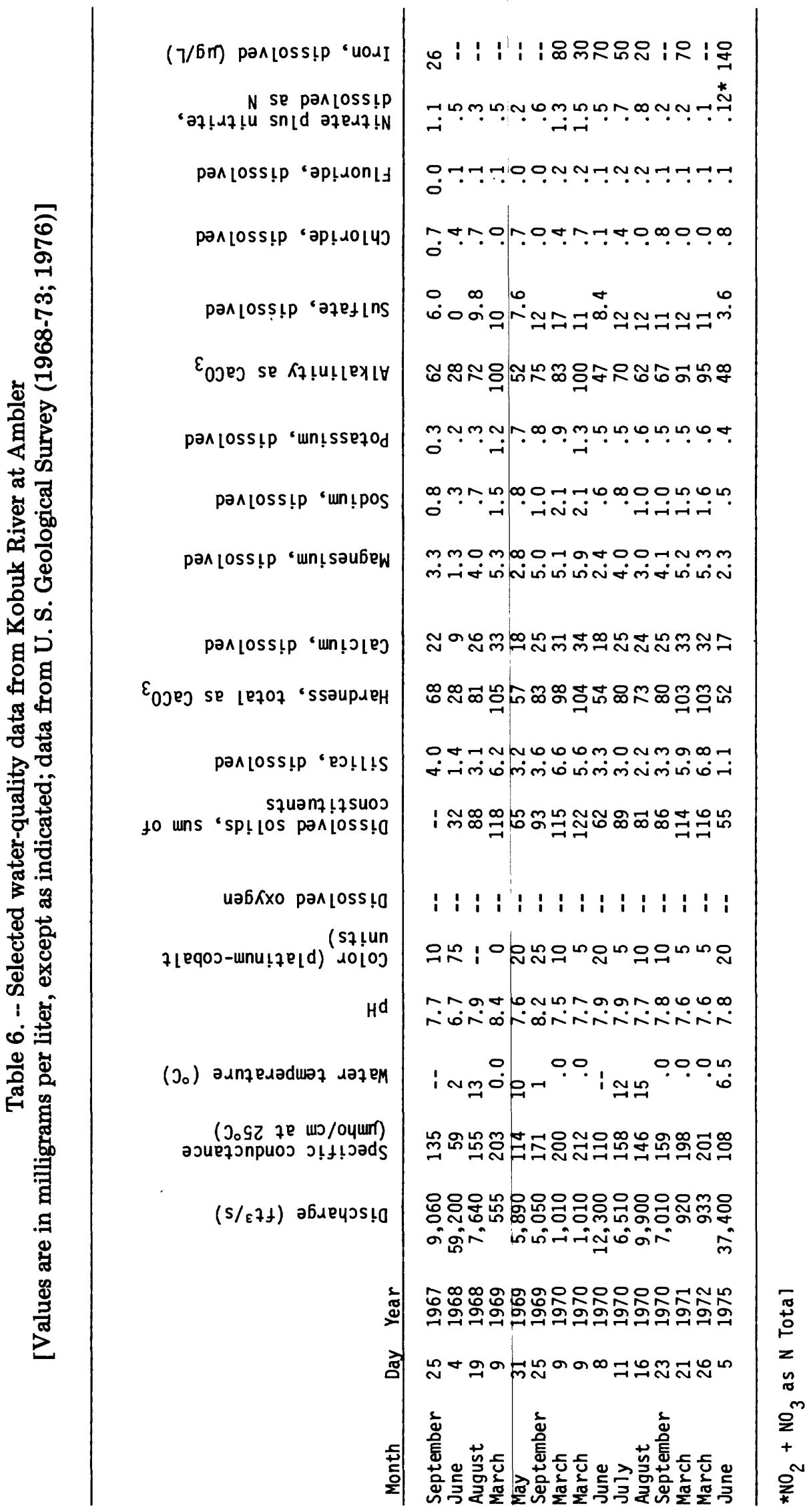




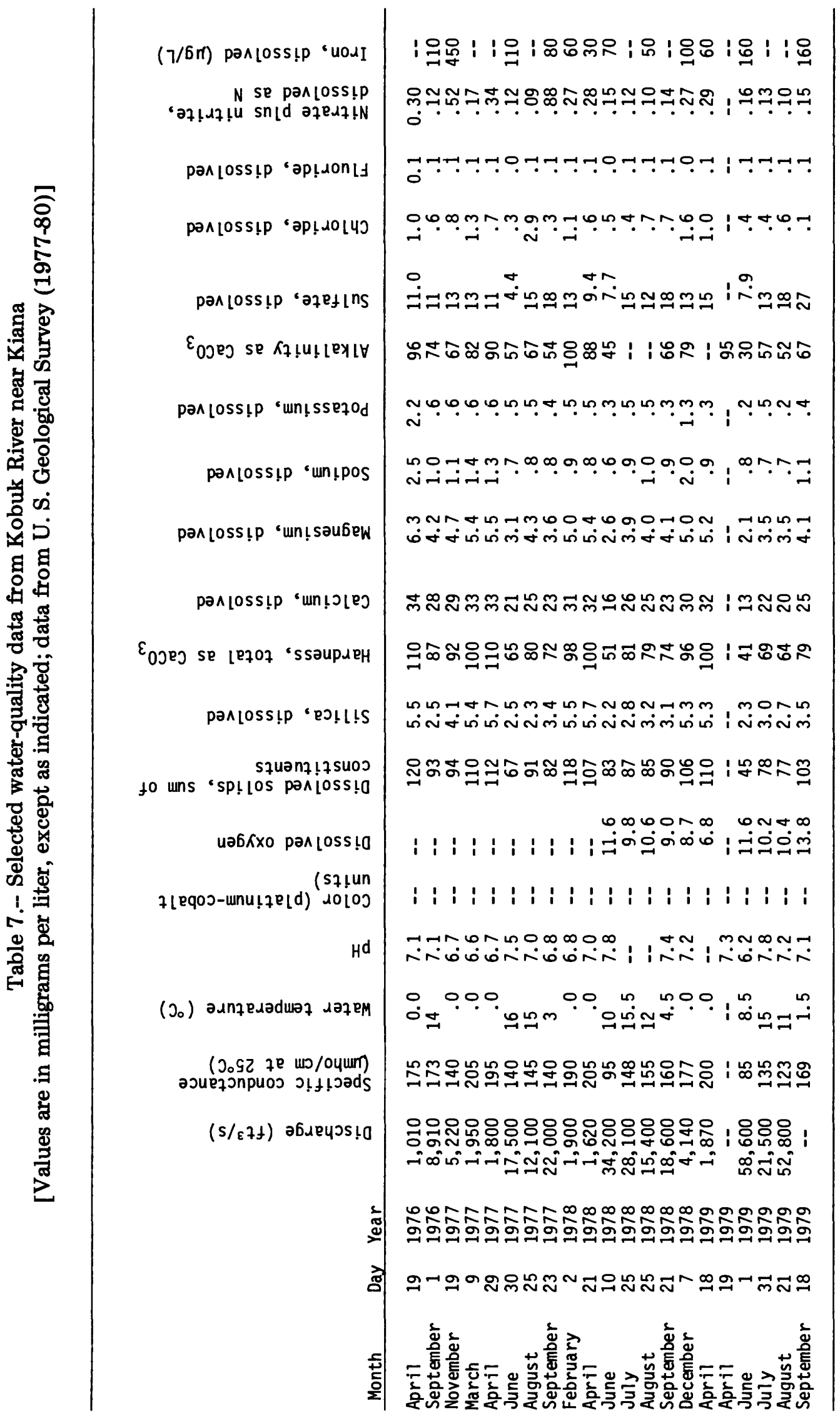


Table 8. -- Water quality and related parameters from selected sites in Kobuk River Basin, August 1979 Dissolved constituents were analyzed from samples filtered through a 0.45 -micron membrane filter.

\begin{tabular}{|c|c|c|c|c|c|c|}
\hline \multirow{4}{*}{$\begin{array}{l}\text { Parameters and } \\
\text { constituents }\end{array}$} & 1 & 2 & 3 & 4 & 5 & 6 \\
\hline & $\begin{array}{l}\text { Kobuk R. ab } \\
\text { Walker LK } \\
\text { outlet }\end{array}$ & $\begin{array}{c}\text { Walker Lk } \\
\text { outlet }\end{array}$ & $\begin{array}{l}\text { Nuturukti } \\
\text { Lk outlet }\end{array}$ & $\begin{array}{l}\text { Kobuk R. ab } \\
\text { Lower Kobuk } \\
\text { Canyon }\end{array}$ & $\begin{array}{l}\text { Reed R. } \\
\text { Hot Spring } \\
\text { nr Kobuk }\end{array}$ & $\begin{array}{l}\text { Reed. R. } \\
\text { nr mouth }\end{array}$ \\
\hline & 11 & 11 & 14 & 13 & 15 & 15 \\
\hline & $17: 30$ & $07: 30$ & $14: 10$ & $09: 20$ & $15: 25$ & $09: 45$ \\
\hline \multirow{5}{*}{$\begin{array}{l}\text { Discharge }\left(\mathrm{ft}^{3} / \mathrm{s}\right)^{\star} \\
\text { Specific conductance (umho/cm } \\
\left.\text { at } 25^{\circ} \mathrm{C}\right) \\
\text { Water temperature }\left({ }^{\circ} \mathrm{C}\right) \\
\mathrm{pH} \text {. } \\
\text { Color (platinum-cobalt units) }\end{array}$} & 1,090 & 1,160 & 47 & 2,380 & 0.3 & 1,640 \\
\hline & 175 & 130 & 65 & 160 & 750 & 110 \\
\hline & 10.5 & 14.5 & 17.5 & 14 & 47.5 & 9.5 \\
\hline & 7.7 & 7.9 & 6.8 & 7.9 & 6.9 & 7.2 \\
\hline & & & & & & \\
\hline $\begin{array}{l}\text { Turbidity (nephelometric turbidity } \\
\text { units) }\end{array}$ & 0.25 & 0.15 & 0.35 & 0.35 & 0.70 & 0.30 \\
\hline $\begin{array}{l}\text { Dissolved oxygen }(\mathrm{mg} / \mathrm{L}) \\
\text { Dissolved solids, residue at }\end{array}$ & -- & -- & -- & -- & -- & -- \\
\hline $180^{\circ} \mathrm{C}(\mathrm{mg} / \mathrm{L}) * \star$ & -- & 70 & -- & 82 & 498 & 55 \\
\hline Dissolved solids, calculated & & & & & & \\
\hline \multirow{2}{*}{$\begin{array}{l}\text { sum }(\mathrm{mg} / \mathrm{L}) \\
\text { Silica, dissolved (mg/L) }\end{array}$} & -- & 82 & -- & 89 & 543 & 61 \\
\hline & -- & 2 & -- & 2.1 & 85 & 2.7 \\
\hline \multirow{4}{*}{$\begin{array}{l}\text { Hardness }\left(\mathrm{mg} / \mathrm{L} \text { as } \mathrm{CaCO}_{3}\right) \\
\text { Calcium, dissolved }(\mathrm{mg} / \mathrm{L}) \\
\text { Magnesium, dissolved }(\mathrm{mg} / \mathrm{L}) \\
\text { Sodium, dissolved (mg/L) } \\
\text { Potassium, dissolved (mg/L) }\end{array}$} & -- & $\begin{array}{l}68 \\
23\end{array}$ & -- & $\begin{array}{l}77 \\
26\end{array}$ & $\begin{array}{l}64 \\
24\end{array}$ & \\
\hline & -- & 2.5 & -- & 2.9 & 1 & 1.9 \\
\hline & -- & 0.6 & -- & 0.7 & 160 & 0.9 \\
\hline & -- & 1.1 & -- & 0.9 & 12 & 0.7 \\
\hline \multirow{5}{*}{$\begin{array}{l}\left.\text { Alkalinity (mg/L as } \mathrm{CaCO}_{3}\right) \\
\text { Sulfate, dissolved (mg/L) } \\
\text { Chloride, dissolved (mg/L) } \\
\text { Fluoride, dissolved (mg/L) } \\
\text { Nitrate plus nitrite, dissolved } \\
\quad \text { (mg/L as } \mathrm{N})\end{array}$} & 79 & 60 & 31 & 68 & 313 & 39 \\
\hline & -- & 11 & -- & 14 & 53 & 13 \\
\hline & -- & 0.2 & -- & 0.3 & 12 & 0.1 \\
\hline & -- & 0.1 & -- & 0.1 & 8.2 & 0.2 \\
\hline & -- & 1.2 & -- & 0.22 & 0.17 & 0.31 \\
\hline \multirow{3}{*}{$\begin{array}{l}\text { Phosphorus, dissolved (mg/L as P) } \\
\text { Iron, dissolved ( } \mu \mathrm{g} / \mathrm{L}) \\
\text { Manganese, dissolved }(\mu \mathrm{g} / \mathrm{L})\end{array}$} & -- & 0.00 & -- & 0.00 & 0.00 & 0.00 \\
\hline & -- & 10 & -- & 80 & 30 & 50 \\
\hline & -- & 1 & -- & 6 & 70 & 6 \\
\hline
\end{tabular}




\begin{tabular}{|c|c|c|c|c|c|c|c|c|}
\hline 7 & 8 & 9 & 10 & 11 & 12 & 13 & 14 & 15 \\
\hline $\begin{array}{l}\text { Minakokosa } \\
\text { Lk outlet }\end{array}$ & $\begin{array}{l}\text { Kobuk R. ab } \\
\text { Sulakpoatokvik } \\
\text { Creek }\end{array}$ & $\begin{array}{l}\text { Lake } \\
\text { Selby } \\
\text { outlet }\end{array}$ & $\begin{array}{c}\text { Kobuk R. bl } \\
\text { Selby R. }\end{array}$ & $\begin{array}{c}\text { Pah R. } \\
\text { nr mouth }\end{array}$ & $\begin{array}{l}\text { Killak R. } \\
\text { nr mouth }\end{array}$ & $\begin{array}{l}\text { Mauneluk } R \text {. } \\
\mathrm{nr} \text { mouth }\end{array}$ & $\begin{array}{l}\text { Kolliioksak } \\
\text { Lk outlet }\end{array}$ & $\begin{array}{c}\text { Kogoluktuk R. } \\
\text { nr mouth }\end{array}$ \\
\hline 14 & 16 & 16 & 17 & 17 & 18 & 18 & 18 & 19 \\
\hline $15: 30$ & $09: 25$ & $15: 00$ & $10: 20$ & $14: 05$ & $14: 25$ & $11: 00$ & $16: 20$ & $11: 35$ \\
\hline 88 & 6,930 & 332 & 7,240 & 458 & 92 & 2,980 & $0.5 \mathrm{e}$ & 2,540 \\
\hline $\begin{array}{l}70 \\
16 \\
7.7 \\
0\end{array}$ & $\begin{array}{c}135 \\
10.5 \\
7.3 \\
0\end{array}$ & $\begin{array}{l}85 \\
17 \\
7.5 \\
10\end{array}$ & $\begin{array}{c}135 \\
13 \\
7.5 \\
0\end{array}$ & $\begin{array}{l}80 \\
13.5 \\
7.1 \\
60^{\circ}\end{array}$ & $\begin{array}{c}55 \\
7.5 \\
6.5 \\
45\end{array}$ & $\begin{array}{c}155 \\
9 \\
7.4 \\
25\end{array}$ & $\begin{array}{l}45 \\
13.5 \\
6.2 \\
60\end{array}$ & $\begin{array}{c}180 \\
9 \\
7.3 \\
25\end{array}$ \\
\hline $\begin{array}{l}0.35 \\
--\end{array}$ & $\begin{array}{l}0.45 \\
--\end{array}$ & $\begin{array}{l}0.30 \\
--\end{array}$ & 0.30 & 0.85 & $\begin{array}{l}0.50 \\
13.5\end{array}$ & 0.65 & $\begin{array}{l}2 \\
7.5\end{array}$ & $\begin{array}{c}0.85 \\
11.8\end{array}$ \\
\hline-- & -- & -- & -- & 51 & -- & -- & -- & 104 \\
\hline$=$ & -- & $\begin{array}{l}-- \\
--\end{array}$ & -- & 51 & $\begin{array}{l}-- \\
--\end{array}$ & $\begin{array}{l}-- \\
--\end{array}$ & -- & $\begin{array}{l}103 \\
2.9\end{array}$ \\
\hline -- & -- & -- & -- & 39 & -- & -- & -. & 89 \\
\hline-- & -- & -- & -- & 11 & -- & -- & -- & 29 \\
\hline-- & -- & -- & -- & 2.9 & -- & -- & -- & 4 \\
\hline-- & -- & -- & - & 2.1 & -- & -- & -- & 0.9 \\
\hline-- & -- & -- & -- & 0.2 & -- & -- & -- & 1 \\
\hline 24 & 53 & 23 & 54 & 35 & 22 & 56 & 24 & 64 \\
\hline-- & -- & -- & -- & 6.4 & -- & -- & $\ldots$ & 26 \\
\hline-- & -- & -- & -- & 0.5 & -- & -- & -- & 0.3 \\
\hline-- & -- & -- & -- & 0.1 & -- & -- & -- & 0.1 \\
\hline-- & -- & -- & -- & 0.02 & -- & -- & -- & 0.13 \\
\hline -- & -- & -- & -- & 0.02 & -- & -- & -- & 0.00 \\
\hline-- & -- & -- & - & 650 & -- & -- & -- & 90 \\
\hline-- & -- & -- & -- & 20 & -- & -- & -- & 10 \\
\hline
\end{tabular}


Table 8. -- Water quality and related parameters from selected sites in Kobuk River Basin, August 1979 - continued

\begin{tabular}{|c|c|c|c|c|c|c|}
\hline Site number & 16 & 17 & 18 & 20 & 21 & 22 \\
\hline $\begin{array}{l}\text { Site name } \\
\text { Day } \\
\text { Time }\end{array}$ & $\begin{array}{l}\text { Kobuk R. } \\
\frac{a b \text { Kobuk }}{24} \\
\frac{24: 45}{15: 4}\end{array}$ & $\begin{array}{l}\text { Kobuk R. } \\
\text { b] Kobuk } \\
\frac{25}{10: 50}\end{array}$ & $\begin{array}{l}\text { Kobuk R. bl } \\
\text { Shungnak } \\
\frac{25}{13: 25} \\
\end{array}$ & $\begin{array}{c}\text { Ruby C at } \\
\text { Bornite } \\
\frac{21}{18: 25}\end{array}$ & $\begin{array}{c}\text { Shungnak R. } \\
n r \text { mouth } \\
\text { nr Shungnak } \\
23 \\
16: 10 \\
\end{array}$ & $\begin{array}{c}\text { Ambler R. } a b \\
\text { Redstone R. } \\
\frac{19}{16: 09} \\
\end{array}$ \\
\hline $\begin{array}{l}\text { Discharge }\left(\mathrm{ft}^{3} / \mathrm{s}\right) * \\
\text { Specific conductance (umho/cm } \\
\left.\text { at } 25^{\circ} \mathrm{C}\right) \\
\text { Water temperature }\left({ }^{\circ} \mathrm{C}\right) \\
\mathrm{pH} \\
\text { Color (platinum-cobalt units) }\end{array}$ & $\begin{array}{r}21,900 \\
165 \\
12 \\
7.3 \\
30\end{array}$ & $\begin{array}{r}-- \\
170 \\
11.5 \\
7.3 \\
20\end{array}$ & $\begin{array}{r}150 \\
12 \\
7.5 \\
25\end{array}$ & $\begin{array}{r}80 \\
235 \\
6.5 \\
7.5 \\
20\end{array}$ & $\begin{array}{c}1,520 \\
127 \\
11 \\
7.6 \\
20\end{array}$ & $\begin{array}{c}5,030 \\
170 \\
10 \\
7.9 \\
25\end{array}$ \\
\hline $\begin{array}{l}\text { Turbidity (nephelometric turbidity } \\
\text { units) } \\
\text { Dissolved oxygen (mg/L) } \\
\text { Dissolved solids, residue at } \\
180^{\circ} \mathrm{C}(\mathrm{mg} / \mathrm{L}) \star \star \\
\text { Dissolved solids, calculated } \\
\text { sum (mg/L) } \\
\text { Silica, dissolved (mg/L) }\end{array}$ & $\begin{array}{l}0.20 \\
11 \\
95 \\
95 \\
3.4\end{array}$ & 10.8 & $\begin{array}{l}0.20 \\
10.8 \\
--\end{array}$ & $\begin{array}{l}0.20 \\
11.6 \\
130 \\
129 \\
3\end{array}$ & $\begin{array}{l}0.40 \\
12.9 \\
-\end{array}$ & $\begin{array}{r}0.40 \\
11.4 \\
--\end{array}$ \\
\hline $\begin{array}{l}\left.\text { Hardness (mg/L as } \mathrm{CaCO}_{3}\right) \\
\text { Calcium, dissolved (mg/L) } \\
\text { Magnesium, dissolved (mg/L) } \\
\text { Sodium, dissolved (mg/L) } \\
\text { Potassium, dissolved (mg/L) }\end{array}$ & $\begin{array}{r}83 \\
27 \\
3.7 \\
0.8 \\
0.7\end{array}$ & $\begin{array}{l}-- \\
-- \\
-- \\
--\end{array}$ & $\begin{array}{l}-- \\
-- \\
-- \\
-- \\
--\end{array}$ & $\begin{array}{r}120 \\
37 \\
6.2 \\
0.5 \\
0.0\end{array}$ & $\begin{array}{l}-- \\
-- \\
-- \\
--\end{array}$ & $\begin{array}{l}-- \\
-- \\
-- \\
--\end{array}$ \\
\hline $\begin{array}{l}\left.\text { Alkalinity (mg/L as } \mathrm{CaCO}_{3}\right) \\
\text { Sulfate, dissolved (mg/L) } \\
\text { Chloride, dissolved (mg/L) } \\
\text { Fluoride, dissolved (mg/L) } \\
\text { Nitrate plus nitrite, dissolved } \\
\quad \text { (mg/L as } \mathrm{N})\end{array}$ & $\begin{array}{l}59 \\
23 \\
0.2 \\
0.1 \\
0.13\end{array}$ & $\begin{array}{l}63 \\
-- \\
-- \\
--\end{array}$ & $\begin{array}{l}56 \\
-- \\
-- \\
--\end{array}$ & $\begin{array}{c}103 \\
17 \\
0.4 \\
0.1 \\
0.07\end{array}$ & $\begin{array}{l}51 \\
-- \\
-- \\
--\end{array}$ & $\begin{array}{l}71 \\
-- \\
-- \\
-- \\
--\end{array}$ \\
\hline $\begin{array}{l}\text { Phosphorus, dissolved (mg/L as } \mathrm{P}) \\
\text { Iron, dissolved ( } \mu \mathrm{g} / \mathrm{L}) \\
\text { Manganese, dissolved }(\mu \mathrm{g} / \mathrm{L})\end{array}$ & $\begin{array}{l}0.01 \\
100 \\
9\end{array}$ & $\begin{array}{l}-- \\
--\end{array}$ & $\begin{array}{l}-- \\
- \\
-\end{array}$ & $\begin{array}{l}0.00 \\
40 \\
7\end{array}$ & $\begin{array}{l}-- \\
-- \\
--\end{array}$ & $\begin{array}{l}-- \\
--\end{array}$ \\
\hline
\end{tabular}

$\star_{e}=$ estimated

$\star \star$ Dissolved residue is calculated from the sum of following constituents: $\mathrm{Ca}, \mathrm{Mg}, \mathrm{Na}, \mathrm{K}, \mathrm{alkalinity,} \mathrm{Cl}, \mathrm{SO}_{4}$, and $\mathrm{SiO}_{2}$ 


\begin{tabular}{|c|c|c|c|c|c|c|c|c|}
\hline 23 & 24 & 25 & 26 & 27 & 29 & 30 & 31 & 35 \\
\hline $\begin{array}{l}\text { Redstone } R \text {. } \\
n r \text { Ambler }\end{array}$ & $\begin{array}{l}\text { Kobuk R. } \\
\text { at Ambler }\end{array}$ & $\begin{array}{c}\text { Jade } C \text {. } \\
\text { nr Ambler }\end{array}$ & $\begin{array}{l}\text { Kobuk R. } \\
\text { bl Jade C. }\end{array}$ & $\begin{array}{l}\text { Akillik R. } \\
\text { ab Hunt R. } \\
\text { nr Ambler }\end{array}$ & $\begin{array}{l}\text { Kavet } \mathrm{C} . \\
\text { at mouth } \\
\text { nr Kiana }\end{array}$ & $\begin{array}{l}\text { Salmon R. ab } \\
\text { Kitlik R. } \\
\text { nr Kiana }\end{array}$ & $\begin{array}{l}\text { Kitlik R. } \\
\text { nr Kiana }\end{array}$ & $\begin{array}{l}\text { Kobuk } R . \\
\text { at Kiana }\end{array}$ \\
\hline$\frac{22}{13: 45}$ & $\frac{27}{13: 58}$ & $\frac{22}{12: 24}$ & $\frac{28}{10: 23}$ & $\frac{22}{10: 19}$ & $\begin{array}{c}29 \\
11: 49 \\
\end{array}$ & $\begin{array}{c}23 \\
10: 23 \\
\end{array}$ & $\begin{array}{c}23 \\
12: 59 \\
\end{array}$ & $\frac{30}{14: 44}$ \\
\hline 1,100 & -- & 150 & 50,800 & $3,700 \mathrm{e}$ & 55 & 4,400 & 851 & -- \\
\hline $\begin{array}{r}100 \\
8 \\
7 \\
60\end{array}$ & $\begin{array}{r}150 \\
8.5 \\
7.5 \\
30\end{array}$ & $\begin{array}{c}62 \\
6.5 \\
6.8 \\
20\end{array}$ & $\begin{array}{c}145 \\
9 \\
7.7 \\
40\end{array}$ & $\begin{array}{c}95 \\
7 \\
6.9 \\
20\end{array}$ & $\begin{array}{c}220 \\
8 \\
7.8 \\
50\end{array}$ & $\begin{array}{c}185 \\
7.5 \\
7.5 \\
15\end{array}$ & $\begin{array}{l}55 \\
7.5 \\
6.5 \\
5\end{array}$ & $\begin{array}{c}230 \\
9 \\
7.5 \\
40\end{array}$ \\
\hline $\begin{array}{l}0.50 \\
12.1\end{array}$ & $\stackrel{2}{11.3}$ & $\begin{array}{c}0.40 \\
12.2\end{array}$ & $\begin{array}{l}0.70 \\
11.6\end{array}$ & $\begin{array}{l}0.80 \\
11.8\end{array}$ & $\begin{array}{r}3.5 \\
11.3\end{array}$ & $\begin{array}{l}0.60 \\
11.8\end{array}$ & $\begin{array}{l}0.15 \\
11.6\end{array}$ & $\begin{array}{l}0.30 \\
11.1\end{array}$ \\
\hline-- & -- & -- & 86 & -- & 128 & 136 & 29 & 130 \\
\hline $\begin{array}{l}-- \\
--\end{array}$ & -- & $\begin{array}{l}-- \\
--\end{array}$ & $\begin{array}{r}97 \\
2.5\end{array}$ & -- & $\begin{array}{r}132 \\
6.4\end{array}$ & $\begin{array}{l}138 \\
2.7\end{array}$ & $\begin{array}{l}33 \\
2.6\end{array}$ & $\begin{array}{r}129 \\
2.2\end{array}$ \\
\hline $\begin{array}{l}-- \\
-- \\
-- \\
--\end{array}$ & $\begin{array}{l}-- \\
-- \\
-- \\
--\end{array}$ & $\begin{array}{l}-- \\
-- \\
-- \\
--\end{array}$ & $\begin{array}{r}91 \\
29 \\
4.5 \\
0.5 \\
0.3\end{array}$ & $\begin{array}{l}-- \\
-- \\
-- \\
--\end{array}$ & $\begin{array}{c}120 \\
40 \\
4.8 \\
1.6 \\
0.3\end{array}$ & $\begin{array}{r}110 \\
33 \\
7.6 \\
0.7 \\
0.1\end{array}$ & $\begin{array}{l}24 \\
7.4 \\
1.4 \\
0.5 \\
0.0\end{array}$ & $\begin{array}{r}120 \\
35 \\
7.9 \\
0.6 \\
0.1\end{array}$ \\
\hline $\begin{array}{l}43 \\
-- \\
-- \\
--\end{array}$ & $\begin{array}{l}75 \\
-- \\
-- \\
--\end{array}$ & $\begin{array}{l}31 \\
-- \\
-- \\
--\end{array}$ & $\begin{array}{l}73 \\
15 \\
0.3 \\
0.1\end{array}$ & $\begin{array}{l}47 \\
-- \\
-- \\
--\end{array}$ & $\begin{array}{r}117 \\
4.5 \\
0.5 \\
0.1\end{array}$ & $\begin{array}{l}67 \\
51 \\
0.3 \\
0.1\end{array}$ & $\begin{array}{c}14 \\
11 \\
0.1 \\
0.1\end{array}$ & $\begin{array}{l}97 \\
23 \\
0.6 \\
0.1\end{array}$ \\
\hline- & - & -- & 0.12 & -- & 0.56 & 0.52 & 0.05 & 0.09 \\
\hline $\begin{array}{l}-- \\
--\end{array}$ & $\begin{array}{l}-- \\
--\end{array}$ & $\begin{array}{l}-- \\
-- \\
--\end{array}$ & $\begin{array}{c}0.01 \\
100 \\
7\end{array}$ & $\begin{array}{l}-- \\
-- \\
--\end{array}$ & $\begin{array}{c}0.02 \\
1,800^{0} \\
50\end{array}$ & $\begin{array}{l}0.00 \\
20 \\
20\end{array}$ & $\begin{array}{l}0.00 \\
50 \\
8\end{array}$ & $\begin{array}{c}0.00 \\
130 \\
8\end{array}$ \\
\hline
\end{tabular}


Specific conductance of water in the Kobuk River ranged from $135 \mu \mathrm{mho} / \mathrm{cm}$ above Sulakpoatokvik Creek and below Selby River to 230 umho/cm at Kiana. Values for tributaries ranged from $55 \mu \mathrm{mho} / \mathrm{cm}$ in the Kitlik River to $235 \mu \mathrm{mho} / \mathrm{cm}$ in Ruby Creek. Lake-outlet water had specific conductance values ranging from $45 \mu \mathrm{mho} / \mathrm{cm}$ at Kollioksak Lake to $130 \mu \mathrm{mho} / \mathrm{cm}$ at Walker Lake. Reed River Hot Spring had a specific conductance of $750 \mu \mathrm{mho} / \mathrm{cm}$.

The flow of Reed River Hot Spring issued from two main openings when the spring was visited on August 15. A discharge of $0.30 \mathrm{ft}^{3} / \mathrm{s}$ was measured at the orifice having the greater flow; no measurements were made at the other orifice. Field waterquality measurements were made and a sample was collected for laboratory analysis. The concentration of lead in a sample from the spring was estimated by a semiquantitative method to be about $1,000 \mu \mathrm{g} / \mathrm{L}$; due to method accuracy, another analys is would be required to verify that value.

The relatively high temperature $\left(47.5^{\circ} \mathrm{C}\right.$ on August 15) of the water at Reed River Hot Spring is apparently conducive to the abundant growth of algae and aquatic plants on the spring-bottom surfaces. Nearby terrestrial plant growth is also luxuriant for this Arctic region -- large areas of ferns and several stands of cottonwood trees are present. The bottoms and adjacent shore areas of pools and channels downstream from the spring outlet are encrusted by chalky white mineral deposits.

\section{Late Winter Samples}

In March and April 1980, field water-quality parameters were measured and samples collected at three sites on the Kobuk River and at five tributary sites. Results of the field determination and laboratory analyses of the samples are listed in table 9. Overflow and hazardous ice conditions prevented sampling or discharge measurements in the Shungnak River (site 21); and at Cosmos Creek (site 19) no flow could be detected under approximately $6 \mathrm{ft}$ of ice. Streams in the upper part of the basin, particularly above Kobuk village, could not be sampled because of the onset of "breakup".

Water temperatures were near $0^{\circ} \mathrm{C}$. At that temperature, the solubility of oxygen in water (at normal atmopsheric pressure of $760 \mathrm{~mm} \mathrm{Hg}$ ) is about $14 \mathrm{mg} / \mathrm{L}$. A D0 concentration of $14 \mathrm{mg} / \mathrm{L}$ was measured only in the Kogoluktuk River; DO values measured at four other sites ranged from about 8 to $9 \mathrm{mg} / \mathrm{L}$. At these four sites the source of streamflow is probabiy ground water derived from tundra or the boggy areas that dominate the valley bottoms. The decomposition of inorganic matter in such areas tends to utilize DO and reduce the concentration in water. The DO concentrations measured in winter 1980 were higher than the recommended minimum concentration of 5 $\mathrm{mg} / \mathrm{L}$ for sustaining fish life (National Academy of Sciences, 1972).

Field determinations of alkalinity, specific conductance, and $\mathrm{pH}$ were also made during the winter reconnaissance trip. Alkalinity as $\mathrm{CaCO}_{3}$ ranged from $38 \mathrm{mg} / \mathrm{L}$ in Hunt River near Ambler to $167 \mathrm{mg} / \mathrm{L}$ in Squirrel River near Kiana. Specific conductance ranged from $110 \mu \mathrm{mho} / \mathrm{cm}$ in Hunt River to $330 \mu \mathrm{mho} / \mathrm{cm}$ in Squirrel River. Values of $\mathrm{pH}$ in the tributaries ranged from 6.7 to 7.6 , and was 6.6 in water at the Kobuk River sites. 
Table 9. - Water quality and related parameters from sites in Kobuk River basin, March and April 1980

\begin{tabular}{|c|c|c|c|c|c|c|c|c|}
\hline Site number & 15 & 16 & 28 & 32 & 33 & 34 & 36 & $\frac{37}{K a b u k R}$ \\
\hline Site name & $\begin{array}{l}\text { Kogoluktuk } \\
\text { R. nr mouth }\end{array}$ & $\begin{array}{l}\text { Kobuk R. } \\
\text { ab Kobuk }\end{array}$ & $\begin{array}{l}\text { Hunt R. } \\
\text { nr Ambler }\end{array}$ & $\begin{array}{c}\text { Portage C. } \\
\text { nr Kiana }\end{array}$ & $\begin{array}{l}\text { Canyon C. } \\
\text { nr Kiana }\end{array}$ & $\begin{array}{c}\text { Squirrel R. } \\
\text { nr Kiana }\end{array}$ & $\begin{array}{l}\text { at Okok Pt. } \\
\text { nr Kiana }\end{array}$ & $\begin{array}{l}\text { at mouth } \\
\text { (Riley Channel) }\end{array}$ \\
\hline $\begin{array}{l}\text { Month/Day } \\
\text { Time }\end{array}$ & $\frac{4 / 2}{13: 27}$ & $\frac{4 / 2}{15: 25}$ & $\begin{array}{r}3 / 28 \\
14: 18\end{array}$ & $\begin{array}{r}3 / 25 \\
09: 06\end{array}$ & $\begin{array}{r}3 / 23 \\
15: 20\end{array}$ & $\begin{array}{r}3 / 24 \\
12: 51\end{array}$ & $\begin{array}{c}4 / 5 \\
14: 17\end{array}$ & $\frac{4 / 6}{10: 00}$ \\
\hline \multirow{5}{*}{$\begin{array}{l}\text { Discharge }\left(\mathrm{ft}^{3} / \mathrm{s}\right) \\
\text { Specific conductance } \\
\quad\left(\mu \text { mho } / \mathrm{cm} \text { at } 25^{\circ} \mathrm{C}\right) \\
\text { Water temperature }\left({ }^{\circ} \mathrm{C}\right) \\
\text { pH } \\
\text { Dissolved oxygen }(\mathrm{mg} / \mathrm{L}) \\
\text { Alkalinity }\left(\mathrm{mg} / \mathrm{L} \text { as } \mathrm{CaCO}{ }_{3}\right)\end{array}$} & 63 & 1,240 & 164 & 0.5 est & 1.76 & 26 & 1,860 & -- \\
\hline & & 170 & 110 & 215 & 220 & 330 & 170 & 270 \\
\hline & $\begin{array}{l}0.5 \\
7.1\end{array}$ & $\begin{array}{l}0.0 \\
6.6\end{array}$ & $\begin{array}{l}0.0 \\
6.7\end{array}$ & 0.0 & & & $\begin{array}{l}0.0 \\
6.6\end{array}$ & 0.5 \\
\hline & 14 & 8.9 & 9.1 & -- & -- & 8.5 & 7.9 & -- \\
\hline & 95 & 70 & 38 & -- & -- & 167 & 96 & -- \\
\hline
\end{tabular}

\section{AQUATIC INVERTEBRATES}

The presence or absence of aquatic organisms in a given reach of a stream is influenced by water temperature, $\mathrm{pH}$, DO concentration, type of substrate, and stream velocity. Long-term water-quality conditions have an important bearing on aquatic invertebrates in a stream. These organisms, when considered in the context of groups rather than as individual species, can often be used as an indicator of stream conditions over periods of time much longer than the sampling visits (Hynes, 1970; Hart and Fuller, 1974; Whitton, 1975).

The sampling areas chosen were in most instances the same sites where other information was collected during the trip. Sampling procedure involved placing the dip net on the streambed, then disturbing bottom material upstream from the net to dislodge organisms. These organisms were subsequently carried into the dip net by streamflow. Samples were collected in small riffles, straight reaches, areas having submerged brush and roots, side pools, and at undercut banks. These conditions are typical of those found along this river.

Dip net samples were collected during August from 25 sites (table 10; fig. 4): 5 sites on the Kobuk River, 14 sites on tributaries of the Kobuk, 5 sites near lake outlets, and 1 site at a thermal spring, Reed River Hot Spring. The average number of taxa (insect groups) at each site was 15; the range was 11 to 21 . Large percentages of Cladocera (water fleas) were present in several samples collected near lake outlets. For example, at the Lake Selby site about 8,600 invertebrates, nearly 80 percent of them Cladocera, were collected. At Minakokosa Lake outlet 54 percent of the invertebrates were Cladocera and in the Pah River near its mouth, more than half were Cladocera. The Pah river at this site is a typical slowflowing, Arctic lowland, brown-water stream. Leeches, which are common in lakes and slow-moving water, were also present at this site. In Reed River Hot Spring, in pools and slower flowing sections originating from this spring, and in Reed River itself, Gastropods (snails) were more common than at other sites and were the dominant organisms. In the immediate area of the main orifice at Reed River Hot Spring only Gastropods were observed; however, in the cooler water downstream; Chironomid (midges) and Trichopteran (caddis flies) larvae were present.

Ephemeroptera (mayflies) and Plecoptera (stone flies) are generally associated with natural, undisturbed environments that are biologically healthy. These orders were found at all sites sampled except Reed River Hot Spring. The Diptera family Chironomidae, a major fish-food organism common in Alaskan streams, was well- 
də|⿱中⿰㇀丶㇀

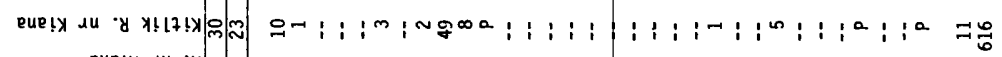

X!lf!x qe y y uoules eue ty $\mathrm{ul}$

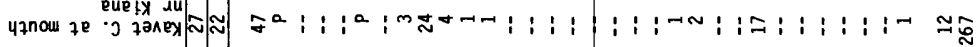
.y zuny qe

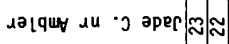
पy au०zs

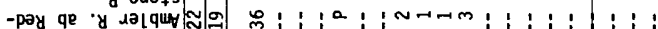
yeu6unus $u$ u

47now du .

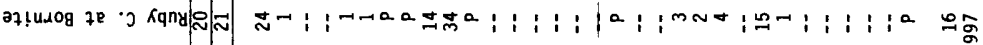

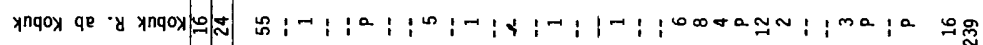

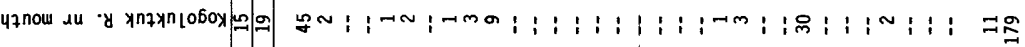
7 al7no

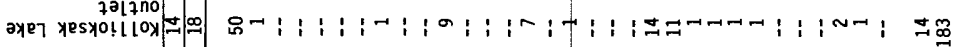

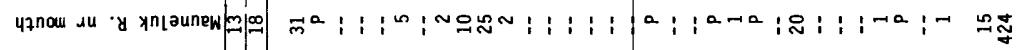

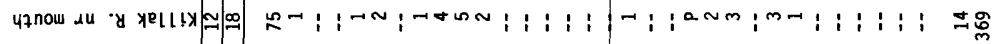

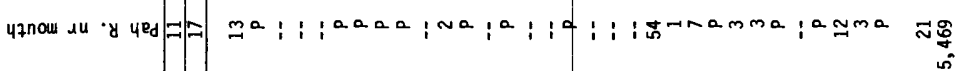

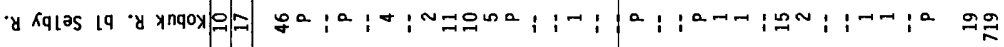

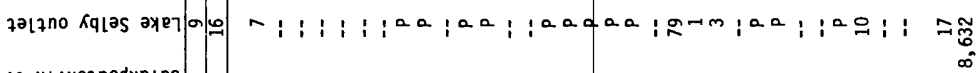

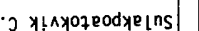

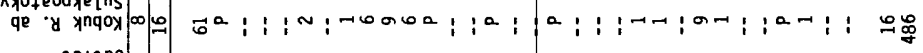

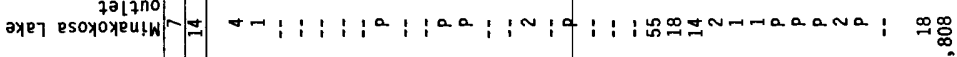

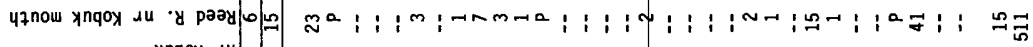

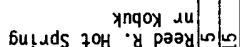

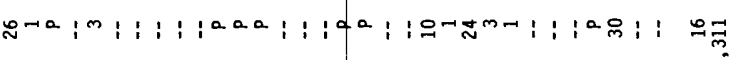

uoxuej xnqoy

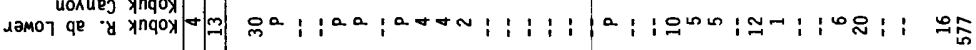

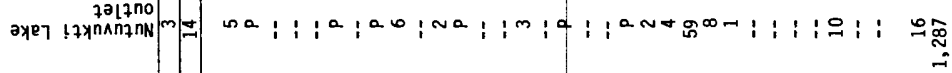

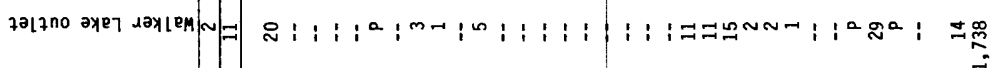

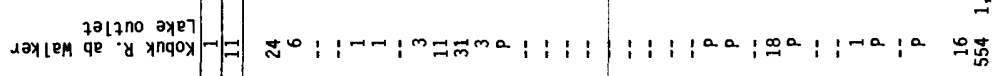

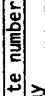

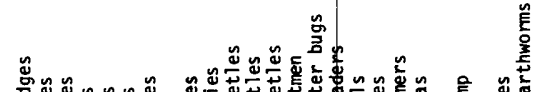

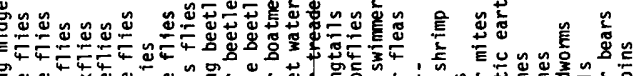

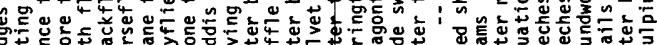

aure แoumos

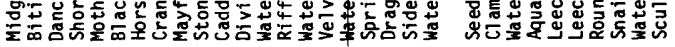

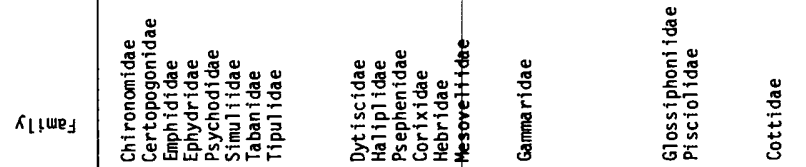

litus

年

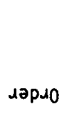

$\iota ә p \wedge 0$

$\frac{\frac{2}{4}}{\stackrel{2}{0}}$

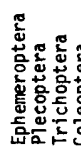

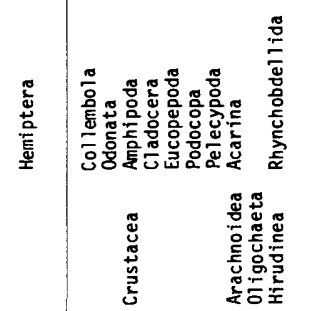

焉

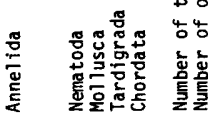


represented at all sites and in most places was the most abundant taxon. The presence of immature stages of stone fijes and mayflies and the overall diverse composition of benthic organisms suggest that the surface waters in the Kobuk River bas in have not been appreciably altered from their.natural state and are generally of excellent quarity.

\section{DATA AND INFORMATION NEEDS FOR FUTURE PLANNING}

Future development in the Kobuk River basin will require planning for water supplies, flood control, and related water-based activities. The types of development proposed or envisioned will govern the type of hydrologic information required to do such planning. Early identification of priorities for water information will allow data collection programs to be tailored to those needs.

Estimates of streamflow characteristics may be required at any site on any stream, but the means of meeting those needs depend on the nature of the project. For large water-development projects such as hydroelectric generation, flood control, or water storage, long-term streamgaging records are desirable. Definition of instream flow requirements for protection or enhancement of aquatic life also should be based on streamgaging records. The accuracy of estimates of streamflow characteristics at any site depends primarily on the length of gaging station record. For example, statistical analysis of Alaska streamgaging records indicates that the standard error of estimate of mean monthly discharge is 12 percent for 10-year records and 6 percent for 25-year records. Prediction accuracy, which is based on these statistics, is a factor in major project planning.

For other types of projects, less precise records may suffice. Streamflow characteristics for ungaged sites may be estimated from streamgaging records of adequate length at nearby, hydrologically similar sites. The selection of a representative gaging station for comparison requires consideration of pertinent factors such as topography, precipitation, geology, and basin size. Again, the accuracy of the estimate for the ungaged site will depend on the length of record at the gaged site and the similarity of the two drainage basins.

Streamflow characteristics useful in many planning applications could be determined by establishing gaging stations at several of the survey sites described in this report. A station on the Kobuk River above Walker Lake outlet or on Reed River near its mouth would represent flow conditions on streams that drain high, rugged mountains but are not affected by lake storage. A station at Walker Lake outlet would provide a record reflecting effects of lake storage. Data from a station on the Pah River would represent a stream draining plains and lowlands.

The gaging station on the Kobuk River near Kiana, established in 1976, is a NASQAN (National Stream-Quality Accounting Network) station that provides records of streamflow discharge and water quality representing a summation from all the Kobuk basin except the Kobuk delta. The Ambler and Squirrel Rivers are both principal streams, tributary to the Kobuk, and streamgaging stations would be required on each to specifically define their flow characteristics.

Knowledge of the flood characteristics of a stream is essential to land-use planning for flood plains. The 1979 survey showed that the water-surface elevations of 
the MEF were at or above bankfull levels at almost all survey sites in the Kobuk River basin. Although the frequency of the MEF is unknown, it is reasonable to consider the MEF as a flood that will probably be exceeded during the next 25 to 50 years. However, until sufficiently long flood-discharge records are available in the Kobuk basin, more reliable estimates of flood magnitude and frequency cannot be made.

\section{SUMMARY}

The Kobuk River basin reconnaissance surveys of 1979 and 1980 were made under unusual weather conditions. The summer survey data were collected during a period of high flows in much of the central and western parts of the basin; the winter survey was not completed as planned because unseasonably warm weather prevented access to much of the basin. Additional surveys could improve understanding of normal streamflow conditions, but this reconnaissance study provided the following significant findings:

- In late winter, runoff of about 0.1 to $0.2\left(\mathrm{ft}^{3} / \mathrm{s}\right) / \mathrm{mi}^{2}$ is probably available from most of the basin, but values approaching no flow may be expected in some smaller tributary basins.

- In late summer 1979 , runoff ranged from about $3\left(\mathrm{ft}^{3} / \mathrm{s}\right) / \mathrm{mi}^{2}$ in the upper Kobuk River and tributaries to about $8\left(\mathrm{ft}^{3} / \mathrm{s}\right) / \mathrm{mi}^{2}$ below Jade Creek in the middle reach of the river.

- Maximum evident flood discharge along the Kobuk River ranges from $22,600 \mathrm{ft}^{3} / \mathrm{s}$ [79.3 $\left.\left(\mathrm{ft}^{3} / \mathrm{s}\right) / \mathrm{mi}^{2}\right]$ above Walker Lake outlet to $71,700 \mathrm{ft}^{3} / \mathrm{s}\left[17.2\left(\mathrm{ft}^{3} / \mathrm{s}\right) / \mathrm{mi}^{2}\right]$ at Kobuk. The MEF was near bankfull stage at most sites.

- Both chemical analyses and the invertebrate communities present in the streams indicate the surface water is generally of excellent quality. 


\section{REFERENCES CITED}

Childers, J.M., and Kernodle, D. R., 1981, Hydrologic reconnaissance of the Noatak River basin, Alaska, 1978: U.S. Geological Survey Water-Resources Investigations 81-1005, $38 \mathrm{p}$.

Hart, C. W., and Fuller, Samuel, 1974, Pollution ecology of fresh water invertebrates: New York, Academic Press, 389 p.

Hynes, H. B. H., 1970, The ecology of running water: Toronto, University of Toronto Press, $555 \mathrm{p}$.

Lamke, R. D., 1979, Flood characteristics of Alaskan streams: U.S. Geological Survey Water-Resources Investigations 78-129, $61 \mathrm{p}$.

Leopold, L. B., and Skibitzke, H. E., 1967, Observations on unmeasured rivers: Geographiska Annaler, v. 49, p. 247-255.

National Academy of Sciences, National Academy of Engineering, 1972 [1974], Waterquality criteria: U.S. Government Printing Office, 594 p.

Riggs, H. C., 1976, A simplified slope-area method for estimating flood discharge in natural channels: U.S. Geological Survey Journal of Research, v. 4, p. 285-291.

Selkregg, L. L., 1976, Alaska regional profiles--Northwest region: University of Alaska, Arctic Environmental Information and Data Center, $265 \mathrm{p}$.

Sigafoos, R. W., 1964, Botanical evidence of floods and flood-plain deposition: U.S. Geological Survey Professional Paper 485-A, 35 p.

U.S. Geological Survey, 1968-73; 1976-80, Water resources data for Alaska: U.S. Geological Survey Water-Data Reports.

Wahrhaftig, Clyde, 1965, Physiographic divisions of Alaska: U.S. Geological Survey Professional Paper 482, 52 p.

Whitton, B. A., 1975, River ecology: Berkeley, University of California Press, v. 2, $725 \mathrm{p}$. 